\title{
LANDSLIDES IN BRITAIN AND THEIR COUNTERMEASURES
}

\section{J. N. Hutchinson*}

\section{INTRODUCTION}

Compared to Japan, Britain is fairly inactive as far as landslides are concerned. The climate is temperate, the relief is moderate and the area is free from destructive earthquakes, having on average about one event per century of surface wave magnitude 6 . Nevertheless, we do have some serious and challenging landslides, chiefly in the three following categories:

I. Coastal landslides, resulting from marine erosion of various degrees of severity,

II. Inland landslides in natunal slopes, commonly comprising the reactivation of Quaternary periglacial features,

III. Man-made landslides in cuttings, fills and waste dumps.

There is an increasing awareness of submarine landslides around Britain, particularly on the continental slope, but these are outside the scope of this paper.

\section{LANDSLIDE TERMINOLOGY AND CLASSIFICATION}

The classifications of Hutchinson (1968) and Skempton a . Hutchinson (1969) are in most common use. For sub-aerial landslides the following, slightly modified scheme is proposed (Fig. 1): Cambering and valley bulging (Horswill and Horton 1976), although important, is hardly a landslide and is thus not included. Rebound and creep phenomena are likewise omitted.

1. ROTATIONAL LANDSLIDES

a) Single

b) Successive (normally retrogressive, occassionally progressive)

c) Multiple

2. COMPOUND LANDSLIDES

a) Strongly non-circular "graben" slides

b) Progressive non-circular slides (rare)

3. TRANSLATIONAL LANDSLIDES

a) Rock slides

i) Planar; blockslide (2-dimensional)

ii) Wedge failure (3-dimensional)

b) Slab slides

c) Spreading failures

d) Debris slides

e) Mudslides; lobate, elongate or sheet-like (may be presentday features or fossil features produced by periglacial solifluction)

f) Bog slides; bog bursts

g) Flow slides

i) involving collapse of loose cohesionless materials

ii) involving impact-collapse of high porosity, weak rock; e.g. Chalk flows

h) * Catastrophic debris flows; Sturzstroms

\footnotetext{
* Department of Civil Engineering, Imperial College of Science and Technology, South Kensington, London SW7 2BU, England.

* Rare or unrepresented in the U.K.
} 
1. ROTATIONAL (approx.circular)

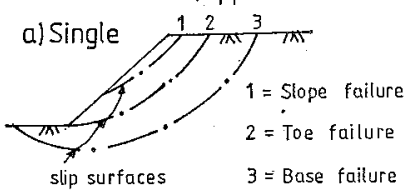

2. COMPOUND (non-circular)

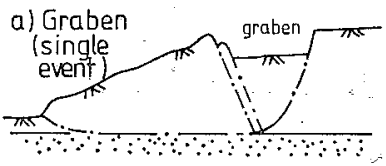

b) Slab slide b) Successive - newest weather to

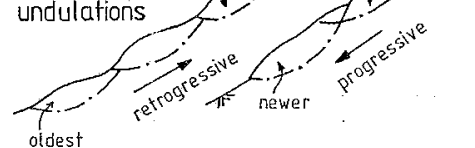
undulations

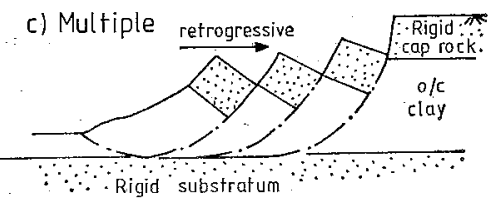

3. TRANSLATIONAL

b) Progressive (rare)

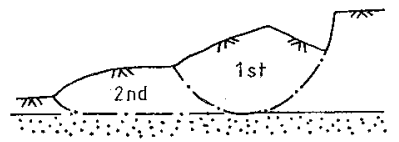

c) Spreading failure Horsts and grabens d) Debris slide

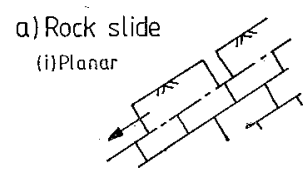

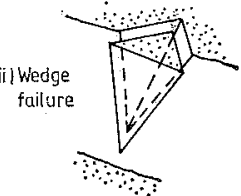

e) Mudslide
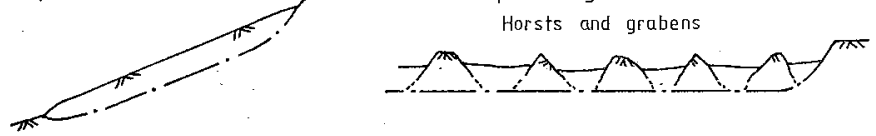

g) Flow slides

(i) in loose cohesion-less material

$$
-
$$

4. TOPPLING

a) Single

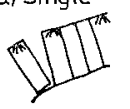

b) Multiple

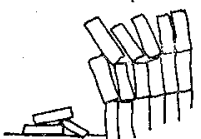

5 FALLS

a) Stone fall

b) Rockfall

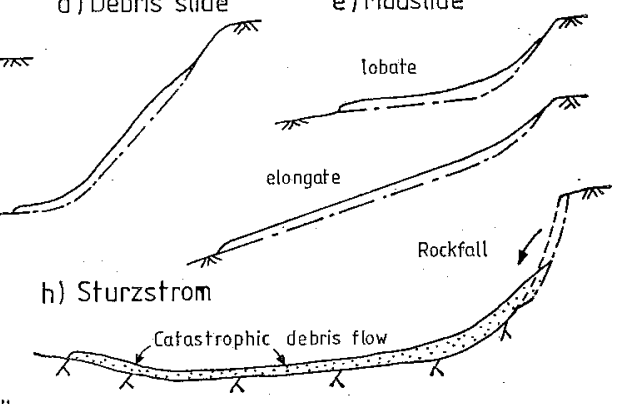

Fig. 1. Classification of landslides in Britain.

i) Mudflows; mud-rock flows

i) Climatic

ii) Volcanic (lahars)

4. TOPPLING FAILURES

a) Single block

b) Multiple blocks

5. FALLS

a) Stone falls

b) Rock falls

6. COMPLEX LANDSLIDES

\section{SOME TYPICAL LANDSLIDES IN BRITAIN}

A brief review of some typical landslides in Britain is given below. The various examples are described under the above-mentioned categories, I to III. Their locations are given in Fig. 2.

\section{Coastal Landslides}

The coasts of Britain exhibit a great variety of geology, morphology, scale and exposure to marine attack and the types of coastal landslide occurring are correspondingly diverse. Some of the more characteristic ones are described under i) to v) below. Average rates of cliff recession range from perhaps only a centimetre or so per year on the hard coasts to a maximum of nearly $8 \mathrm{~m} /$ year (Anon 1951) in the low cliffs of Late Quaternary deposits at Selsey Bill, Sussex. : The ages of the coastal landslides vary accordingly. Among. the oldest in Southern Britain are the deep-seated, rotational slips involving Chalk and Tertiary basalts overlying Lower Jurassic or Triassic clays at Garron Point, Antrim, which are believed to have originated about 14, 000 years ago (Stephens, et al. 1975). In contrast, landslides in the soft cliffs of Pleistocene deposits on the East Anglian coast, for example near Cromer, are often eroded away by the sea within a 
year or so of their occurrence (Hutchinson 1976).

\section{i. in stiff fissured clay undergoing strong toe erosion}

Cliffs of stiff fissured London Clay up to about $40 \mathrm{~m}$ in height are present on both sides of the Thames Estuary. Large landslides occur in these from time to time, particularly on the more exposed, north or north-eastward facing cliffs. Deep-seated, single rotational landslides are the characteristic mode of failure at Warden/Point, Isle of Sheppey, where the average rate of cliff-top recession is around $2 \mathrm{~m} /$ year. Such a failure there in November 1971 is shown in Fig. 3. Further east, near Herne Bay, the sandstone underlying the London Clay rises until only a few metres below sea level. This inhibits the development of deepseated rotational slides and causes the landslides to be of compound, graben type, as illustrated by Fig. 4 (Hutchinson 1973, Bromhead 1978).

ii. in stiff, fissured clay undergoing moderate toe erosion.

On the same London Clay cliffs described above, a very different pattern of landsliding is found where the intensity of toe erosion is only moderate* (Hutchinson 19 73). This is characterized by the formation of mudslides, often within a regular pattern of embayments (Fig. 5). These mudslides are almost stationary during the summer, but move several metres seaward each winter, largely as a result of the undrained loading of their rear parts by debris from their steeper back slopes (Hutchinson and Bhandari 1971). Major mudslides in the London. Clay and other Cenozoic and Mesozoic clays also form around the sides of deep-seated landslides as they degrade (Fig. 6). The largest coastal mudslides in Britain occur in Jurassic clays and shales on the Dorset Coast, at Black Ven. These are over $220 \mathrm{~m}$ wide and can project up to $200 \mathrm{~m}$ out to sea (Conway 1974).

iii. in stiff-fissured clay with a rigid, jointed cap-rock

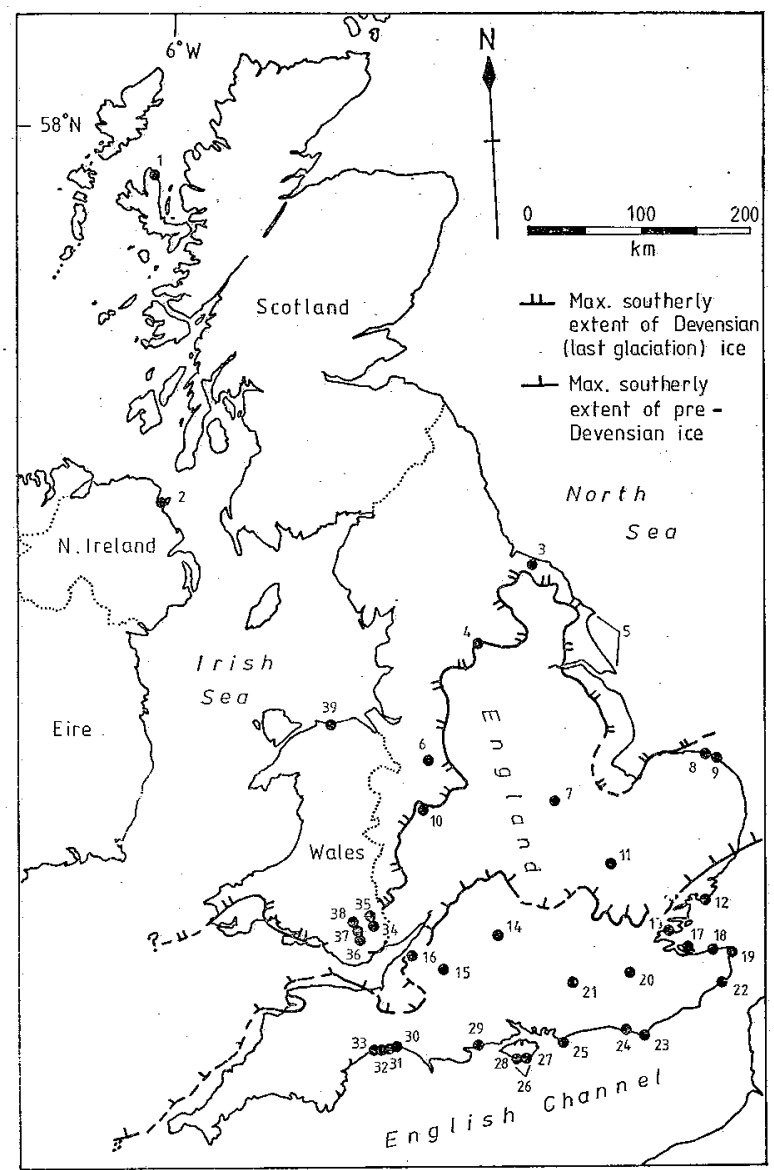

Fig. 2. Map of Britain, showing glacial limits and locations of sites referred to in text: $1-\mathrm{N}$. E. Skye; 2-Garron Point; 3-Boulby; 4-Otley; 5-Holderness coast; 6-Walton's Wood; 7-Barnsdale; 8-Cromer; 9-Trimingham; 10-Jack field; 11-Cambridgeshire; 12-Clacton-on-sea; 13-Hadleigh; 14-Swindon; 15Bradford-on-Avon; 16-Avon Gorge; 17-Warden Point; 18-Herne Bay; 19-Joss Bay; 20-Sevenoaks; 21-Guildford; 22-Folkestone Warren; 23-Beachy Head; 24-Newhaven; 25-Selsey Bill; 26-Undercliff, Isle of Wight; 27-Gore Cliff; 28-Chale; 29-Bournemouth; 30-Black Ven; 31-Lyme Regis; 32-Dowlands; 33-Sidmouth; 34-Llanhilleth; 35-National Colliery; 36-Nantgarw; 37-Cilfynydd; 38-Taren Slip and Aberfan, Taff Vale; 39-Llanddulas.

\footnotetext{
* A "moderate" rate of toe erosion is defined as being broadly in balance with the rate of weathering and debris movement on the cliff slopes, thus bringing about their parallel retreat. In the cliffs under discussion it corresponds to an average rate of cliff-top recession of between about 0.3 and $0.8 \mathrm{~m} /$ year (Hutchinson 1973).
} 


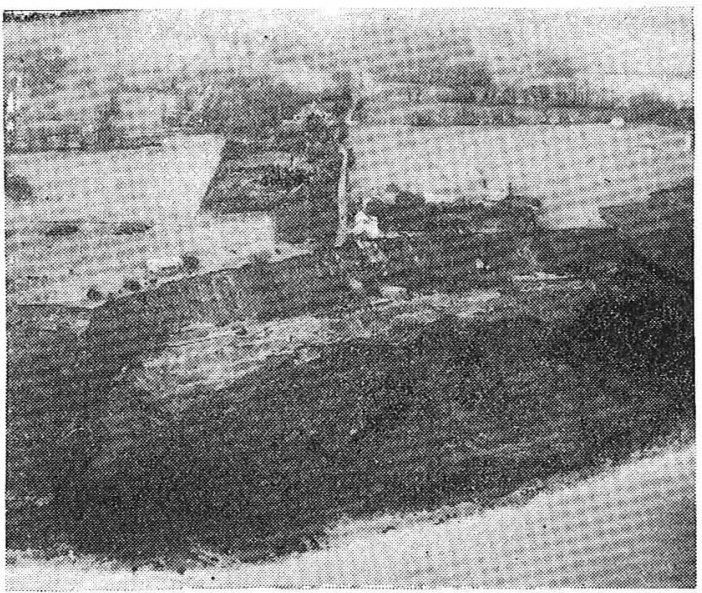

Fig 3. Deep-seated, rotational landslide of November 1971 in London Clay cliffs at Warden Point, Isle of Sheppey, Kent, southern England. (Acknowledgements to the Committee for Aerial Photography, University of Cambridge).

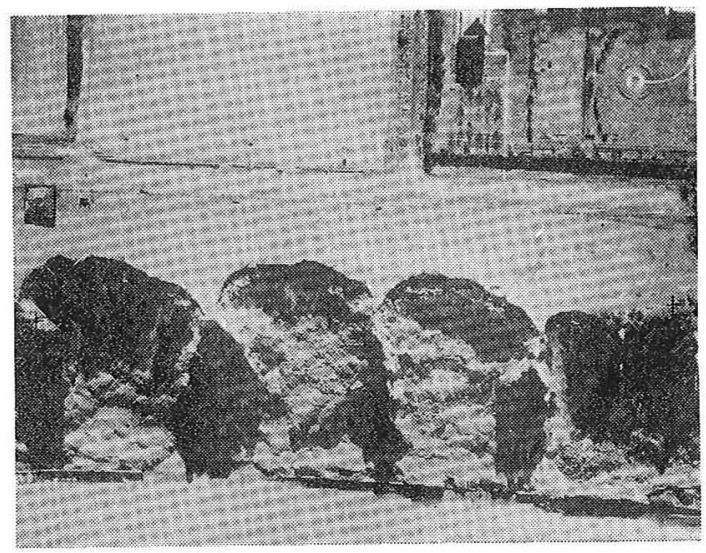

Fig. 5. Regular embayments, occupied by mudslides, in London Clay cliffs near Herne Bay, Kent, southern England in February 1950. (Acknowledgements to Photoflight Ltd).

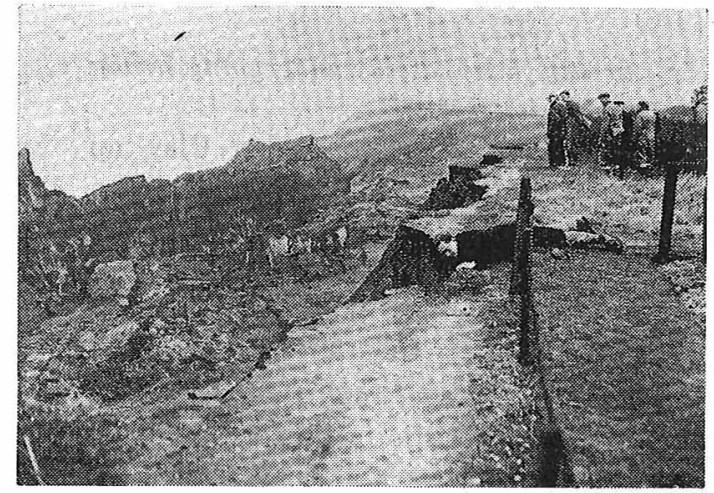

Fig. 4. Compound, graben-type landslide of February 1953 in London Clay cliffs near Herne Bay, Kent, southern England. (Acknowledgements to the Kent Messenger, the County Paper of Kent).

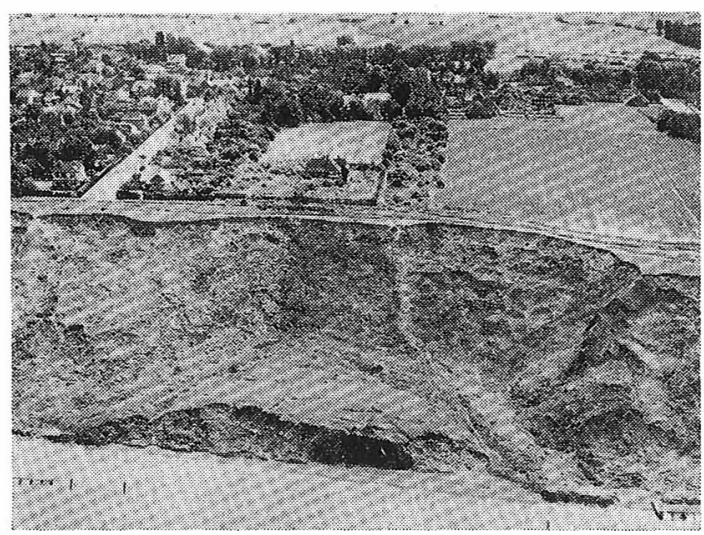

Fig. 6. Lateral mudslides forming on each side of old rotational landslide in London Clay cliffs near Herne Bay, Kent, southern England in February 1950. (Acknowledgements to Photoflight Ltd).

The largest coastal landslides in Britain are associated with situations where a thick, overconsolidated clay stratum is sandwiched between

two stronger rock formations. An example of a single rotational failure in such a setting is provided by the ancient slides at Garron Point in Northern Ireland (Fig. 7), mentioned earlier. In 1839, in a somewhat related geological situation at Dowlands, on the Dorset coast, a large compound slide took place, with very strong graben formation and upheaval of the foreshore. This failure is described by Pitts (1979).

The most characteristic forms of failure in this geological setting are multiple rotational slides. One of the largest such slide is in the north-east of Skye, off the west coast of Scotland, and involves Tertiary basalts overlying Jurassic clays (Fig. 8). In southern England, the most extensive multiple rotational slides are associated with the Cretaceous "Gault" clay, overlain by the Upper Greensand and Chalk. The largest of these slides forms the so-called "Undercliff" of the south coast of the Isle of Wight. This slide complex extends for about $12 \mathrm{~km}$ along the coast, has an average width of 


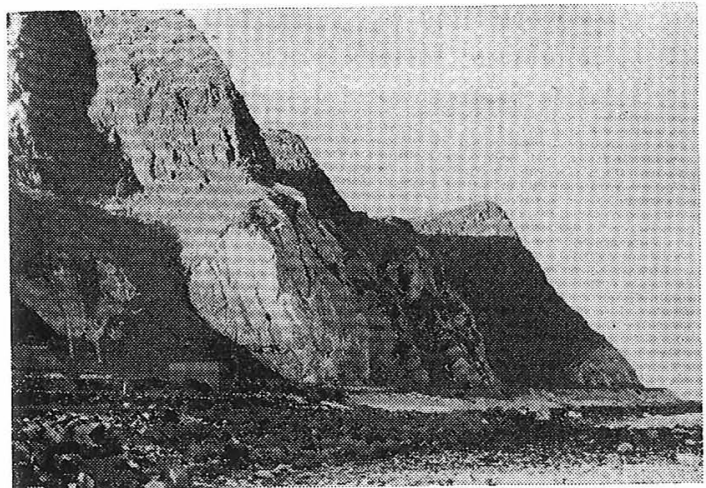

Fig. 7. Deep-seated, rotational landslides at Garron Point, Northern Ireland.

about half a kilometre and is inhabited by over 6,000 people, chiefly concentrated in the rotational slide involving the Chalk and the Gault is that at Folkestone Warren, in Kent. This is traversed by the Dover to Folkestone railway line and has, therefore, been much investigated (e.g. Toms 1953, Wood 1955, Hutchinson et al. 1980). The line was opened in 1844 but has been closed by landsliding over thirty times since then. It is referred to in more detail below.

iv. in Quaternary deposits; mainly tills, commonly with interbedded sands and laminated clays

Such materials form much of the coast of East Anglia. Erosion by the North Sea is fairly intense and the rate of coastal retreat, effected chiefly by landsliding, is high. A rotational slide near Cromer in 1962 is shown in Fig. 9. The slipped masses were eroded back to the line of the cliff toe in about a year. Fig. 10 illustrates similar cliffs further south, near Trimingham. A contractor is attempting to build a system of protection against toe erosion, but is experiencing great difficulties from frequent landslides and mudslides, in addition to the normal difficulties of marine work.

In east Yorkshire, the 60 kilometre long, largely unprotected coast of Holderness is formed of a relatively more homogeneous sequence of Devensian (last glaciation) tills. Under the influence of moderate to strong marine erosion, these cliffs are subject to continual landslides. These frequently consist of slope failures and falls, but base failures are not uncommon. The resulting rate of cliff-top recession averages about $1.2 \mathrm{~m} /$ year (Valentin 1954).

v. in rock

Rock falls of up to a volume of about $1,000,000 \mathrm{~m}^{3}$ occur from time to time from coastal cliffs, chiefly in the Chalk but also in the Upper and Lower Greensand. Less commonly, considerable falls take place from Triassic cliffs, for example that of June 1893 near Sidmouth, Devon (Hutchinson 1983). The highest Chalk cliffs in Britain, at Beachy Head, Sussex, are $170 \mathrm{~m}$ high and modes of failure can be studied more safely and easily in the lower cliffs. Thus, in the fall at Joss Bay, Kent, in $15 \mathrm{~m}$ high cliffs subject to strong toe erosion by the sea, the failure was preceded by the gradual opening of a tension crack, down pre-existing joints, to

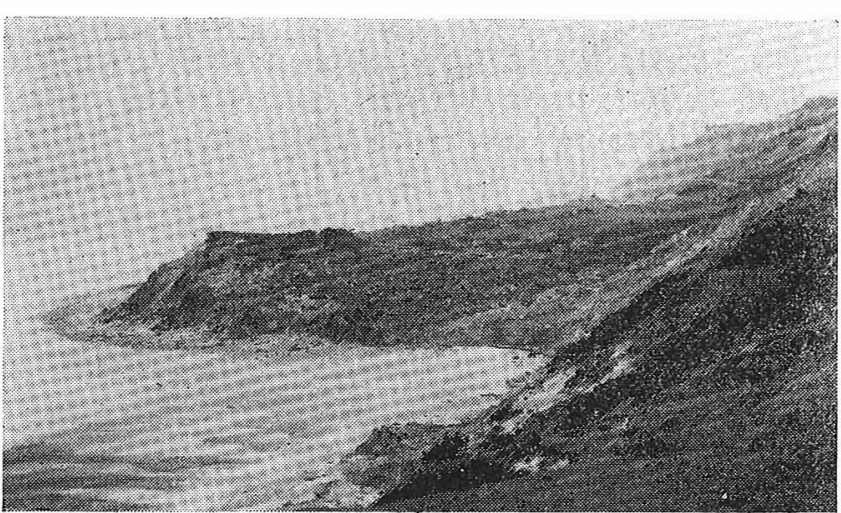

Fig. 9. The landslide of May 1962 near Cromer, Norfolk, East Anglia (after Hutchinson 1976). 
about mid-height of the cliff. This was followed by a shear failure at high angle (ca. $45^{\circ}+\phi^{\prime} / 2$ ) through the root of the mass (Fig. 11). The above process was doubtless assisted by the formation of a wave-cut notch about $0.5 \mathrm{~m}$ deep in the foot of the cliff (Hutchinson 1972, Hoek and Bray 1977).

The behaviour of the debris of these falls is of interest. That from the smaller falls (from Chalk cliffs up to 40 $\mathrm{m}$ or so in height) forms a talus inclined at about $35^{\circ}$ at the base of the cliff, in a normal manner. As the cliff height and slide volume increase, however, a degree of flow appears in the debris and in falls from the higher cliffs (generally of the order of 70 to $150 \mathrm{~m}$ in height) a veritable "chalk flow" can occur which can carry the debris seaward over the near-horizontal wave-cut platform for distances of over four times the cliff height (Fig. 12). The present working hypothesis is that such flow slides occur because of the generation of high porewater pressures through the crushing, under impact, of the relatively weak blocks of high porosity, near-saturated Chalk (Hutchinson 1980, 1983). Similar, but more dangerous flow slides have occurred in quarries for China Clay

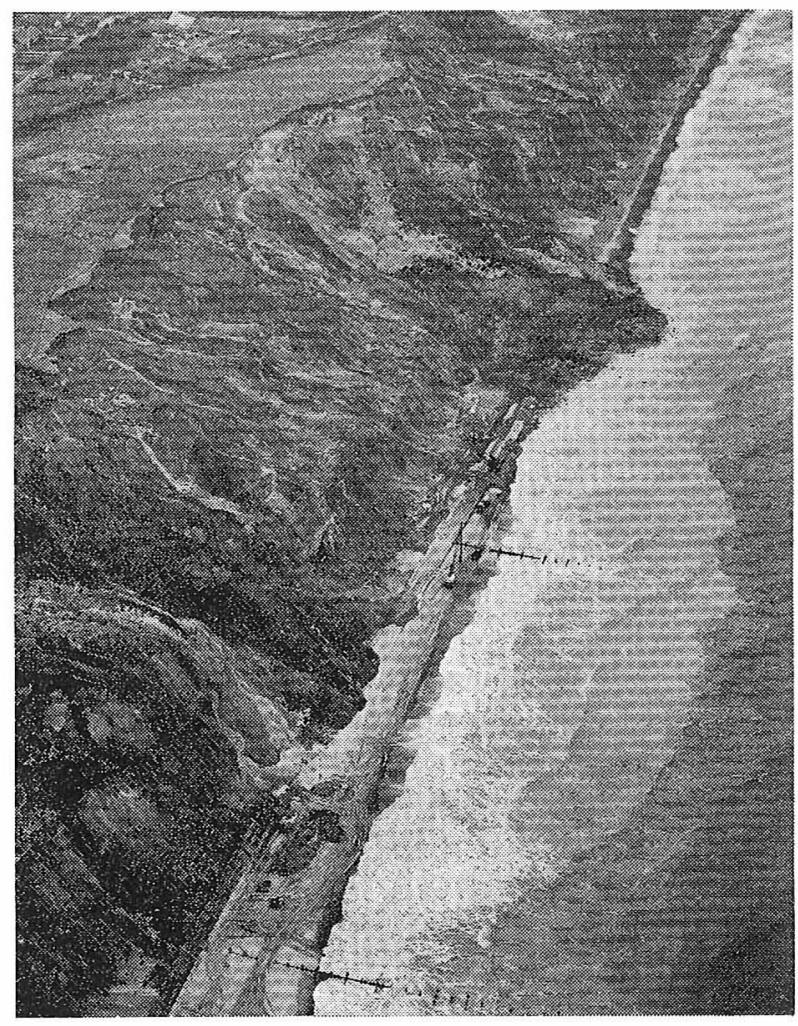

Fig. 10. Landslides and sea defence works in 1974 near Trimingham, Norfolk, East Anglia. (Acknowledgements to Aerofilms Ltd).

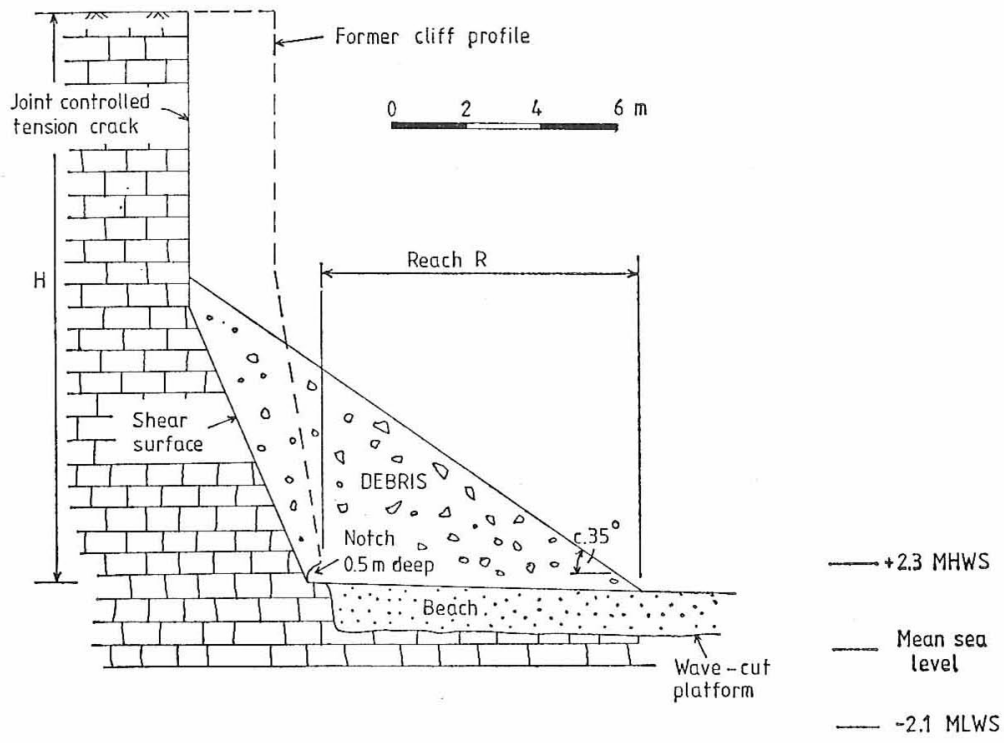

Fig. 11. Cross section of the Chalk fall of early 1966 at Joss Bay, Kent, Southern England (after Hutchinson 1972, 1980). 
(kaolin) in Cornwall. In one such case a fall only 5,000 to $6,000 \mathrm{~m}^{3}$ in volume, from a steep, $45 \mathrm{~m}$ high face, transformed into a flow slide on impact and ran about $100 \mathrm{~m}$ across the near-horizontal quarry floor to kill one man. This suggests that deeply weathered granites, and possibly other deeply weathered igneous rocks, may be even more prone to collapse-generated flow slides than the Chalk (Hutchinson 1983).

Toppling failures occur in both steeply dipping rocks and in horizontally or near-horizontally bedded strata with steep joints. Examples of such failures in the U.K. are described by De Freitas and Watters (1973). A general treatment of toppling is provided by Hoek and Bray (1977) and further consideration of some possible failure mechanisms by Evans (1981). A toppling failure which took place in July 1928 in near-horizontal, steeply jointed Upper Greensand beds at Gore Cliff, part of the rear scarp of the Isle of Wight Undercliff, is illustrated in Fig. 13. The mass involved was estimated to have had a volume of between 50,000 and 100,000 $\mathrm{m}^{3}$.

\section{Inland Landslides in Natural Slopes}

Away from the coast, the present degree of erosional activity in the U.K. is generally slight. It is, of course, significant in some rivers, particularly those such as the Severn and the Avon,

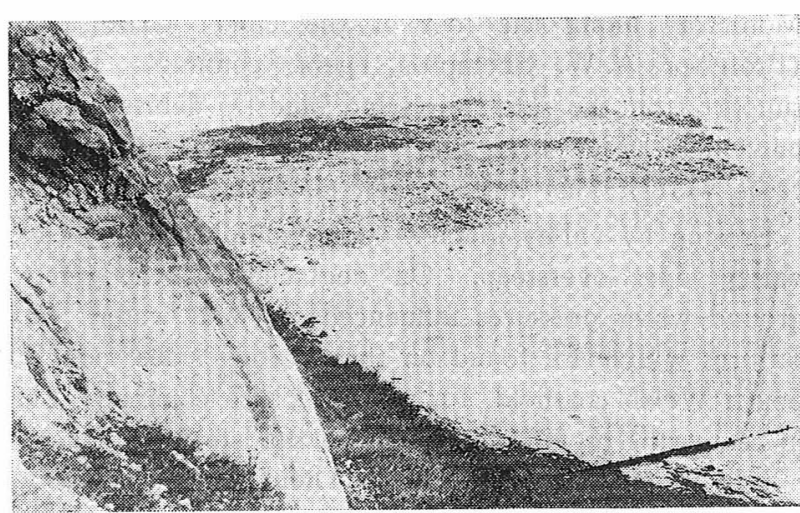

Fig. 12. Debris of the Chalk flow of 31 December 1911 at Abbot's Cliff, Kent, Southern England, (near Folkestone Warren) viewed from the cliff top. (Acknowledgements to Folkestone Public Library).

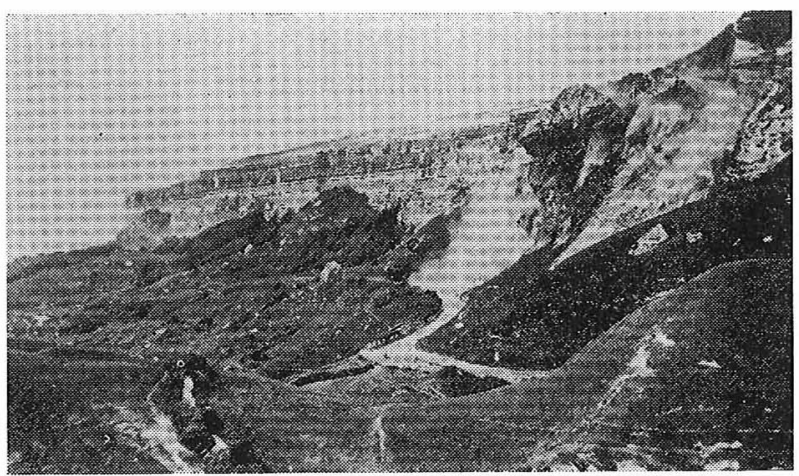

Fig. 13. The toppling failure (in mid-air) of July 1928 at Gore Cliff in the Undercliff of the Isle of Wight, southern England. (Acknowledgements to Dr A. N. Insole, Sandown Museum, Isle of Wight). which suffered major diversions as a result of Pleistocene glaciations. The Jackfield slide in the Upper Coal Measure shales of the Severn Gorge (Henkel and Skempton 1954) is an example of a slide triggered by contemporary fluvial erosion, while the wedge failure in the Carboniferous Limestone forming the sides of the Avon Gorge at Bristol, described by Henkel (1961), may be considered as a delayed response to the earlier fluvial erosion there. In these cases, as in other ways mentioned below, it is the legacies of the Pleistocene which dominate the landslide situation inland.

During the Pleistocene, ice sheets advanced several times over most of the U.K. and severe periglacial effects were felt in the nonglaciated areas (Fig. 2). As a result of the latter, great spreads of solifluction debris, often several metres in thickness, have covered many hillsides. Where this debris is clayey, the solifluction deposits contain numerous slip surfaces at residual strength and may be reactivated by quite minor earthworks. The solifluction sheets and lobes on the Hythe Beds/Weald clay escarpment at Sevenoaks, Kent, dating from the last glaciation and from Zone III of the Late-glacial ( $c a$. 10, 000 years B. P.) were so badly reactivated by earthworks for the new Sevenoaks by-pass that the road had to be largely re-routed, at considerable cost (Skempton and Weeks 1976). Similar problems were encountered in constructing the M4 
Motorway along the foot of the Upper Greensand/Gault escarpment near Swindon, Wiltshire (Professor A.W. Skempton, pers. comm.). The excavation for the motorway removed toe support from the solifliction and landslip debris mantling the scarp slope, and reactivated a major movement (Fig. 14). The morphological signs of past and potential future instability, in this case, were hidden largely, but not entirely, by trees.

Erosion by valley glaciers, for example in Wales, northern England and Scotland, left many valley sides oversteep. On deglaciation, the removal of ice support, and possibly also high ground-water pressures influenced by melt-water, may have tended to trigger many of the large failures which are found on these valley sides today. Failures of this nature in the valleys of the South Welsh coalfield, for example, are common. They are frequently associated with weak beds of seatearths or mudstones within sandstone sequences and may thus have originated as predominantly translational landslides. Their present form, however, is frequently complex. Such a slide, in the Taff Vale, is illustrated in Fig. 15.

Severe erosion was also caused during de-glaciation by glacial lake overflows and, to a lesser extent, by melt-water flowing in glacier marginal channels. Again the resulting long-term landsliding and slope degradation has covered these valley sides with extensive colluvial deposits, generally interlaced by slip surfaces and readily prone to re-activation. The M 6 Motorway was routed over such slopes at Walton's Wood, in Staffordshire. The resulting landslides and their stabilization are described by Early and Skempton (1972).

A further common accompaniment to de-glaciation was the formation of glacial lakes. The deposits within these consist characteristically of varved silts and clays, which can be particularly troublesome in dam foundations and in slopes. The low-angled lower slopes on the west side of the Ebbw Vale, near Llanhilleth, south Wales, are an expression of landslides in underlying glacial lake deposits. These posed difficult problems in designing a new road up this valley, which are mentioned below.

The seaward reaches of the major rivers suffered very active erosion and downcutting in response to the considerable lowering of base level which accompanied the glaciations. This set in train sequences of landsliding which may still be active today. The abandoned, but still unstable, cliff of London Clay at Hadleigh, Essex, is an example of this (Fig. 16). By careful study of the colluvial fabrics, combined with radio-carbon dating of the available organic debris, the colluvium there could be divided into seven stages. The fact that the rear scarp of the slips is encroaching on a 13 th century castle provided useful additional historical information. As shown on the engineering-geological crosssection of the cliff (Fig. 17), it was

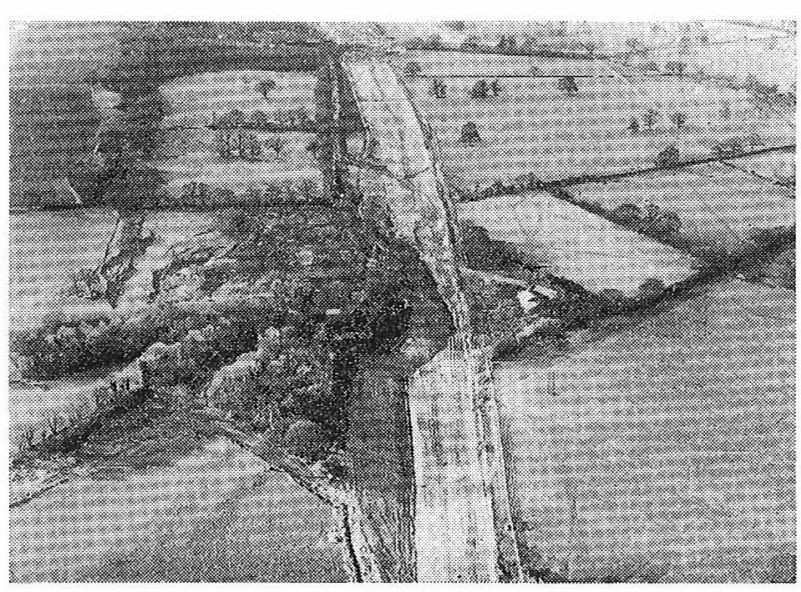

Fig. 14. Translational landslide of December 1969 near Swindon, southern England, reactivated by the earthworks for the M4 Motorway.

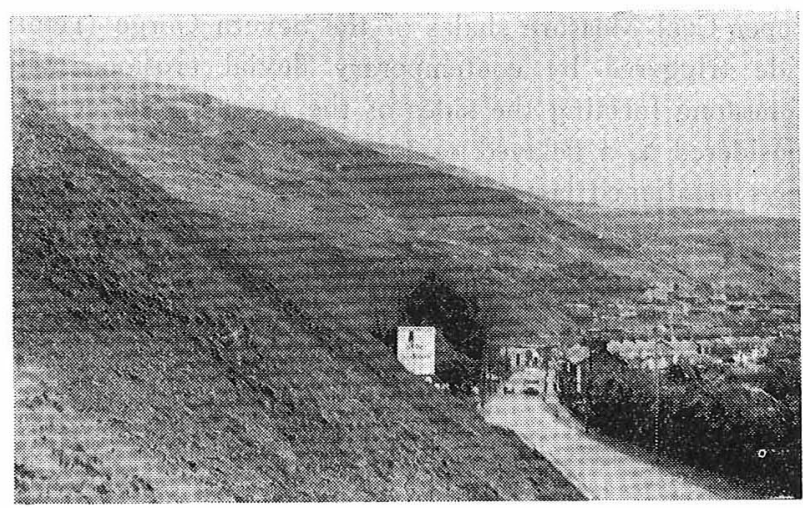

Fig. 15. Ancient complex landslide on the east side of the Taff Vale, south Wales, near Aberfan. 
thus possible to make approximate reconstructions of the cliff profile back to about 10,000 years ago (Hutchinson and Gostelow 1976). The time of abandonment of the Hadleigh Cliff is not precisely known, but is estimated to have been around 15,000 years ago. At present the overall inclination of the degradation zone is still $12.6^{\circ}$ (Fig. 17) and extrapolation indicates that full development of the slope to attain its ultimate angle of stability against landsliding (shown by Hutchinson (1967) to be approximately $8^{\circ}$ for the London Clay) will require a further period of some thousands of years.

\section{Man-made Landslides in Cuttings, Fills and Waste Dumps}

The first major, "modern" earthworks in the U.K. were associated with the canal building era of the 18th and early 19th centuries. As these works followed the contours as far as possible, serious landslides appear to have been relatively uncommon, except in connection with the occasional deep cutting, tunnel portal, or high embankment. During the construction of the Kennet and Avon Canal, for instance, in about 1799, a landslide was caused near Bradford-on-Avon which involved an area of about $28,000 \mathrm{~m}^{2}$. It is of interest that this slide was stabilized by the construction of drainage tunnels (Smiles 1862, vol. 2, pp. 144-145).

The succeeding era of railway construction, on the other hand, with its heavy constraints with regard to allowable gradients, involved much cutting and filling, and slides, generally of modest size, were common. The failure of a retained cutting slope of London Clay at Wembley Hill, London, in 1918 (Fig. 18) and that of a cutting in Weald clay near Sevenoaks, Kent, in 1939 (Terzaghi and Peck 1967, Fig. 49.6) are typical examples and others are described by Skempton (1977). More recently, motorway construction has led to a considerable number of small slides in cuts and fills but, as noted above, the more serious failures in this connection have involved the reactivation of large fossil perigl-

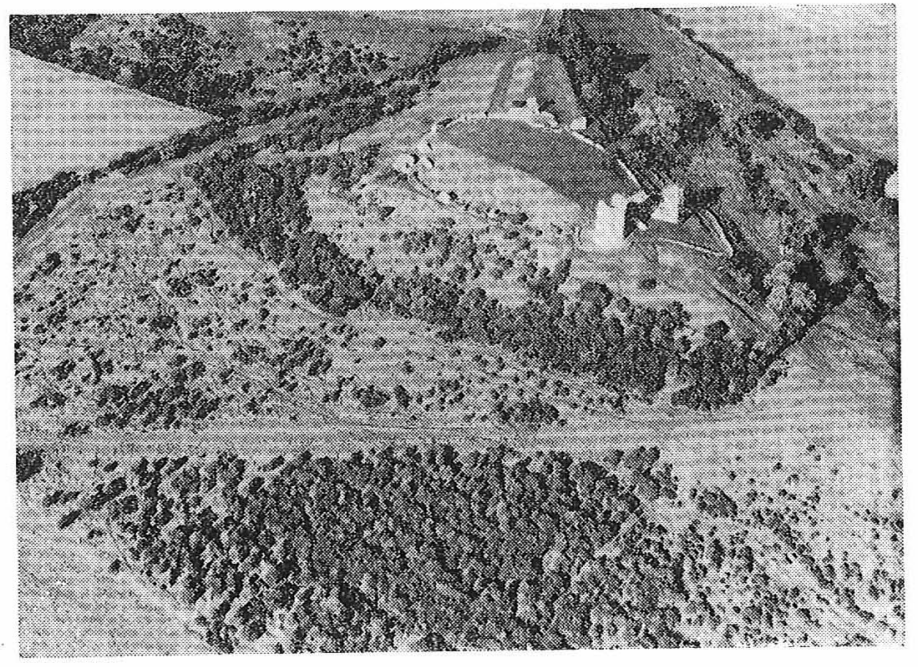

Fig. 16. The degrading, abandoned cliff of London Clay at Hadleigh, southern England. (Acknowledgements to Aerofilms Ltd).

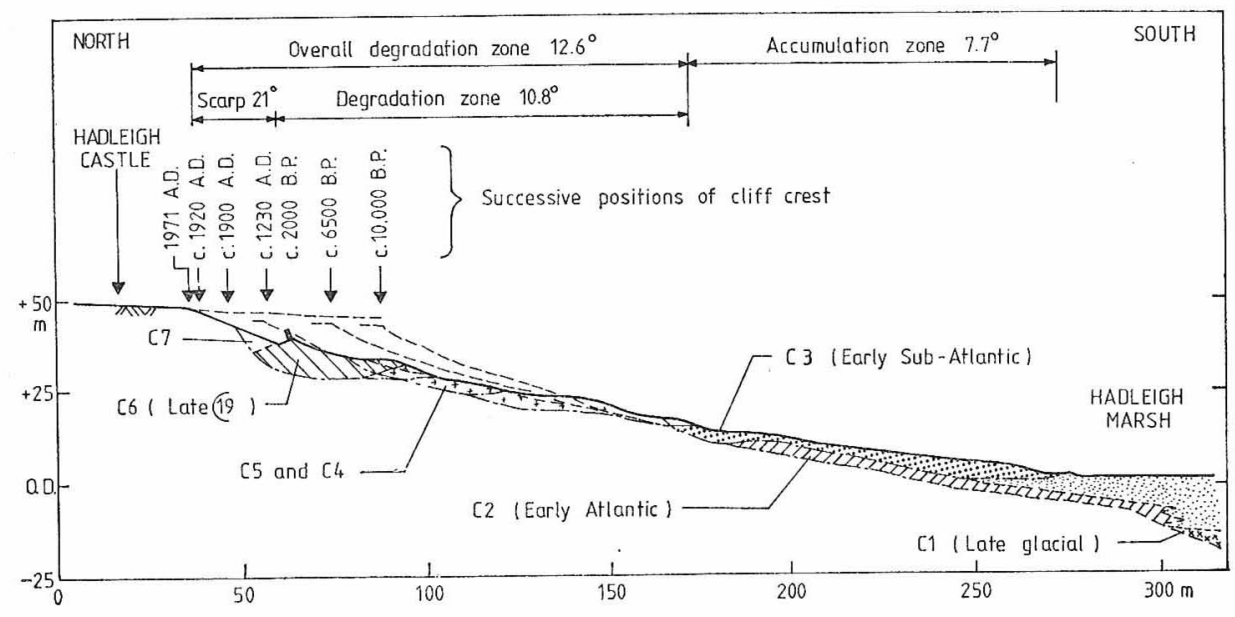

Fig. 17. Cross-section of the abandoned cliff of London Clay at Hadleigh, southern England (after Hutchinson and Gostelow 1976). 
acial landslides.

Our most dangerous man-made landslides are undoubtedly flow slides from waste dumps. The most tragic incident of this type occurred at Aberfan, south Wales, in 1966 when 144 people, most of them school children, were killed by a flow slide from a dump of coal mine waste, loosely placed on an unstable hillside (Fig. 19). The number of fatalities in this single disaster exceeded the deaths caused by natural landslides in the U.K. during the previous few centuries. An unheeded warning of this type of danger was provided in 1939 by the closely similar flowslide from a dump of coal waste at Cilfynydd, only 7 kilometres from Aberfan. Subsequently, similar flowslides have occurred in tips of sand waste from China Clay mining in Cornwall and from several tips of pulverised fuel ash from coal-burning power stations. In view of the increasing production of wastes by the industrialized nations, great attention needs to be given to the avoidance of such flow slides in the future (Bishop 1973).

\section{LANDSLIDE COUNTERMEASURES: SOME EXAMPLES OF CURRENT BRITISH PRACTICE}

\section{General}

The main methods of slope stabilization, which may be used singly or in combination, are:

\section{-Drainage}

-Modification of the slope profile by excavation and/or filling

-Restraining and other structures, including anchors

-Erosion control, both local to the particular site and catchmentwide.

-Miscellaneous methods.

These are reviewed in detail by Hutchinson

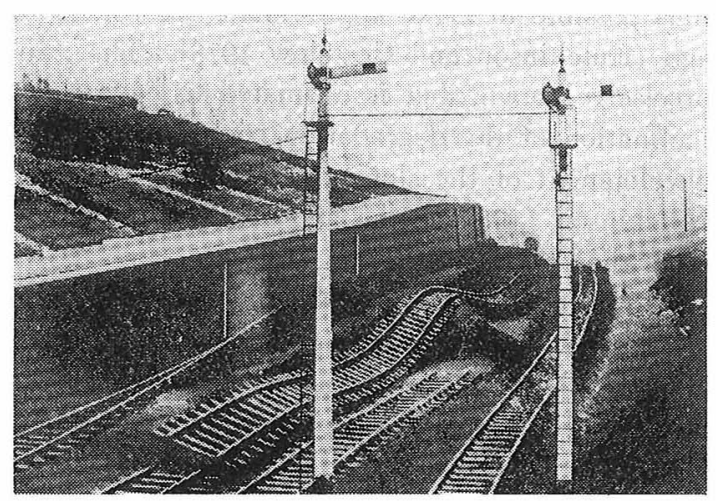

Fig. 18. The failure of a retaining wall and cut slope in the London Clay at Wembley, London, in 1918. (Acknowledgements to "The Engineer").

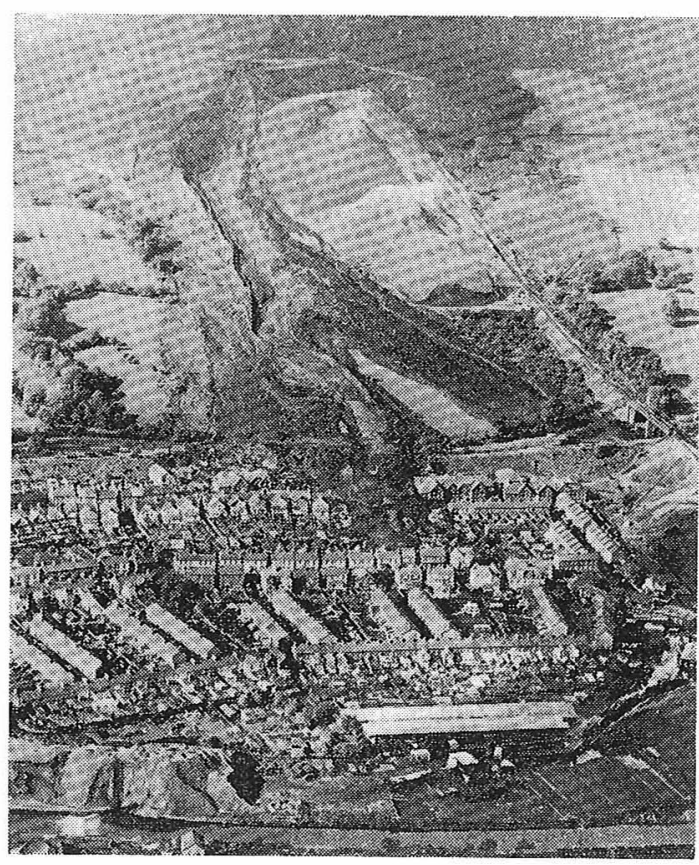

Fig. 19. The flow slide which caused the Aberfan disaster of October 1966.

(1977). The following discussion concentrates on the first three of the above methods, which are those most generally used in Britian at present.

\section{Drainage}

The first task is always to deal with surface water and to lead it away from the landslide area. Concerning sub-surface drainage, two approaches exist. One is to attempt to intercept the ground-water, by cut-off trenches and the like, before it reaches the slide area: this may be practicable for small landslides but is difficult to accomplish reliably in the case of large ones. Furthermore, in some cases the precipitation falling on the slide itself may be important.

The alternative approach is to aim to reduce the ground-water pressures directly at the locations which matter, that is, on the slip surfaces. Only this second approach is discussed here. It should be borne in mind that, in clays, drainage measures may take a year or more to 
become fully effective and additional measures may thus have to be taken to secure stability in the short-term.

i. artesian groundwater

Generally speaking, the higher the pressures in the ground-water, the easier it is to drain. In the case of artesian pressures, once the hydrogeology has been defined it is often an easy matter to reduce these by sinking relief wells. Such wells, consisting of $150 \mathrm{~mm}$ diameter, heavy duty plastic tubes, are currently being installed in the toe area of a large Post-glacial landslide at Taren, south Wales (Fig. 20), to reduce artesian pressures of up to a few metres above ground level (information by courtesy of the Director of Engineering (Transport and Highways), Welsh Office, and Rendel Palmer \& Tritton).

\section{ii. groundwater at shallow depth}

In Britain, many shallow landslides are present on slopes of 5 to $15^{\circ}$ inclination. As, in the winter, groundwater levels are often less than $0.5 \mathrm{~m}$ and rarely more than $2 \mathrm{~m}$ below ground level, such slides can readily be stabilized by relatively shallow drainage. This is most commonly effected by trench drains, cut down the line of steepest slope and backfilled with free-draining granular material (Fig. 21). Drain depths are usually 3.5 to $5.5 \mathrm{~m}$, the latter being the maximum convenient digging depth of the normal tracked back-hoe excavators that are available: drain spacings range from 6 to over $20 \mathrm{~m}$. At the slope foot the discharge of the trench drains is carried away by a collector drain.

A distinction is drawn between trench drains, which do not penetrate the slip suface, and improve stability by drainage alone, and counterfort drains, which do penetrate the slip surface and have an additional, buttressing effect (Fig. 22). It is clearly preferable to use counterfort drains where the slip surface is within reach. In addition to their greater initial effect, they also retain some efficacy even if clogging of the drain should occur in the long-term.

An approximate method for designing trench and counterfort drains has been developed by Hutchinson (1977). Twodimensional flow nets are used to compute the variation of piezometric level between drains in the long-term. An efficiency of drains

$$
\eta=\frac{h_{0}-h}{h_{0}}
$$

is then defined as illustrated (Fig. 23), and curves are derived relating this efficiency to $S / h_{0}$, the ratio of the spacing between the drains to the depth by which they penetrate below the winter piezometric level. As shown by Fig. 24, a comparison of these curves with longterm performance data from six diverse sites is encouraging. Clearly the param-

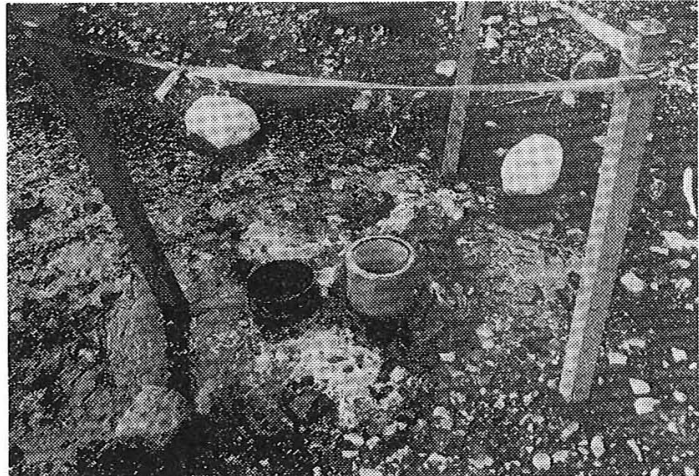

Fig. 20. Bleed well in the toe area of the Taren landslide, Taff Vale, south Wales, discharging artesian ground-water in 1983.

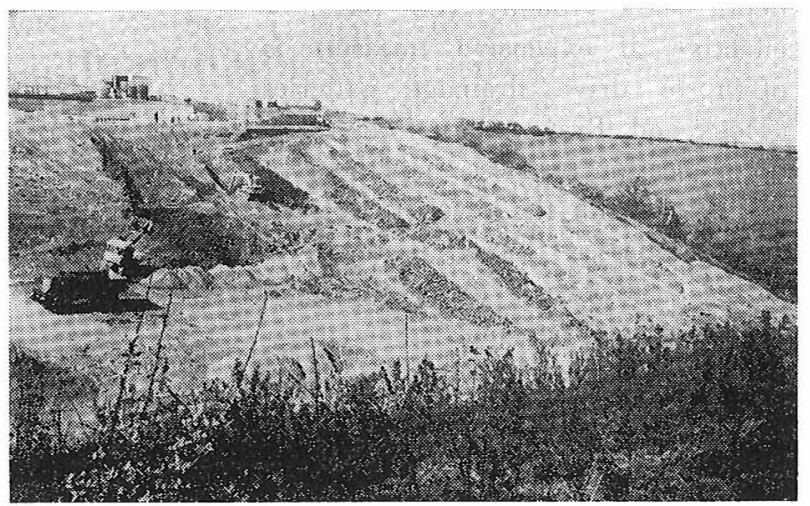

Fig. 21. Drainage trenches under construction in a natural slope of fill at Boulby, northern England. (Acknowledgements to Imperial Chemical Industries Ltd, Agricultural Division, and to the Cleveland Potash Ltd). 
eter $R_{k}$, the ratio of horizontal to vertical permeability, is of prime importance.

An example of the stabilization of a landslide by trench drains is provided by a site at Guildford, Surrey. There a non-circular landslide up to about $8 \mathrm{~m}$ deep occupied a $9^{\circ}$ slope in London Clay. This was of fairly low overall permeability, of around $10^{-6}$ to $10^{-7} \mathrm{~cm} / \mathrm{sec}$ over the relevant depth range, as indicated by the plot of Fig. 25. Nevertheless, trench drains $5 \mathrm{~m}$ deep, with an $S / h_{0}$ ratio of 3.85 , were installed in 1966 and have produced a longterm lowering of piezometric level of about $2 \mathrm{~m}$, which has been sustained over at least 11 years. A comparison of the theoretical predictions and the observed behaviour at this site is shown, in Fig. 26. Since 1967, the site has been occupied by the buildings (generally on bored pile foundations) of the University of Surrey, which are understood to have experienced no distress. A further well-documented case record, for drain trenches in the upper Lias, is provided by Chandler (1977).

iii. groundwater at considerable depth

In deep landslides where the maximum piezometric levels on the slip surface are situated at a considerable depth below ground level, the most effective, if expensive, measure is often to drive drainage galleries (Hoek and Bray 1977). The optimum location of these may theoretically be within the lower part of the slipped masses, close to the slip surface. However, depending upon the nature of these masses and their rate of movement, it may be hazardous to drive such a gallery. Also, galleries constructed within the slide are likely to be destroyed should it suffer a renewal of major movement.

In the coastal landslides of Folkestone Warren, the basal slip surface lies predominantly between about 10 . (a)

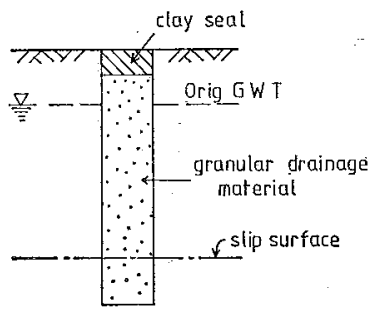

(b)

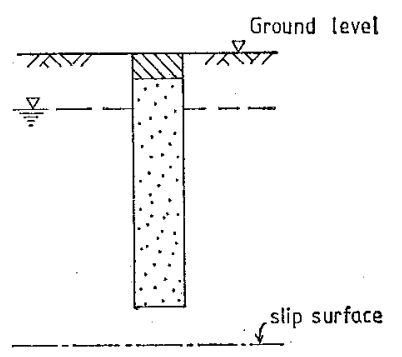

Fig. 22. Basic types of stabilization trenches:

a) counterfort drain, b) trench drain (after Hutchinson 1977).

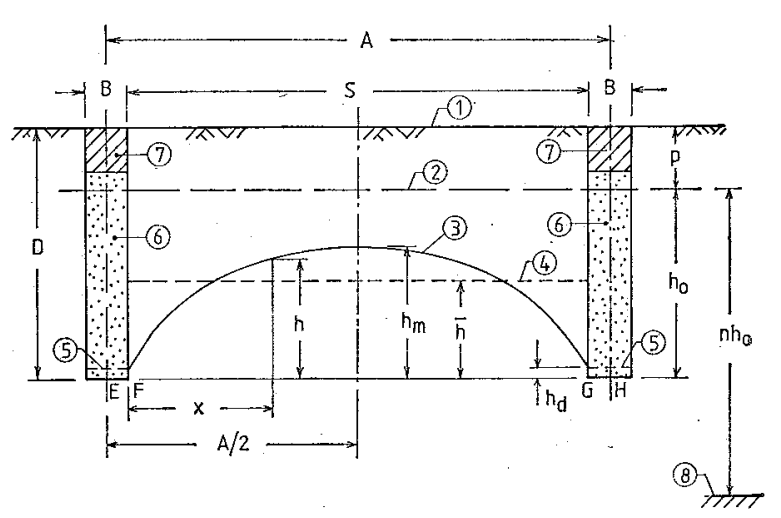

Fig. 23. Cross section of typical trench drains: $1=$ ground surface; $2=$ original piezometric level on plane $\mathrm{EH} ; 3=$ piezometric levels on plane FG after drainage; $4=$ mean piezometric level on plane $\mathrm{FG}$ after drainage; $5=$ mean piezometric levels on drain inverts after drainage; $6=$ trench or counterfort drains; $7=$ clay seal; $8=$ impermeable boundary at depth (after Hutchinson 1977).

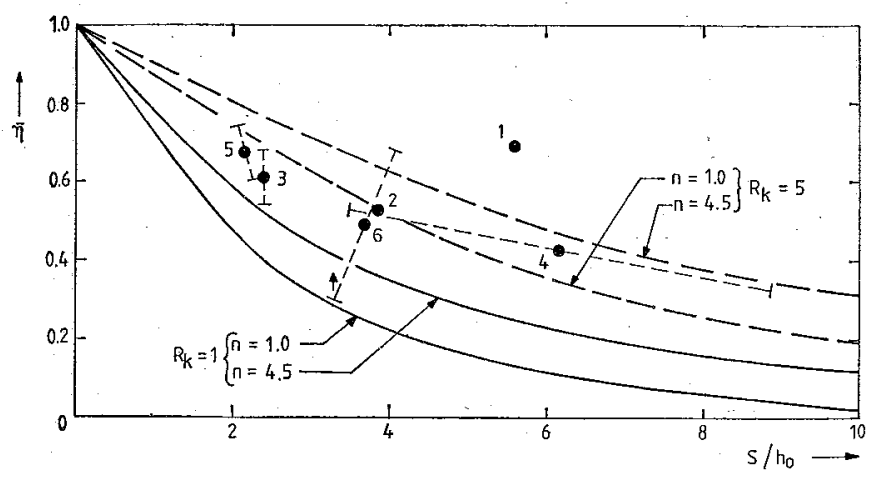

Fig. 24. Comparison of approximate theoretical predictions for the effect of trench drains with field data: $1=$ Sevenoaks; $2=$ Guildford; $3=$ Hodson, near Swindon; $4=$ Burderop Wood, near Swindon; $5=$ Boulby; $6=$ Barnsdale (after Hutchinson 1977). 


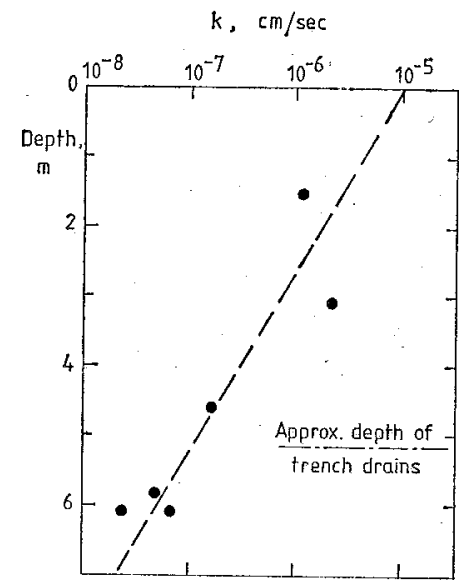

Fig. 25. Variation of permeability (from constant head tests in piezometers) with depth in the London Clay at Guildford, southern England (based on Hutchinson 19 77).

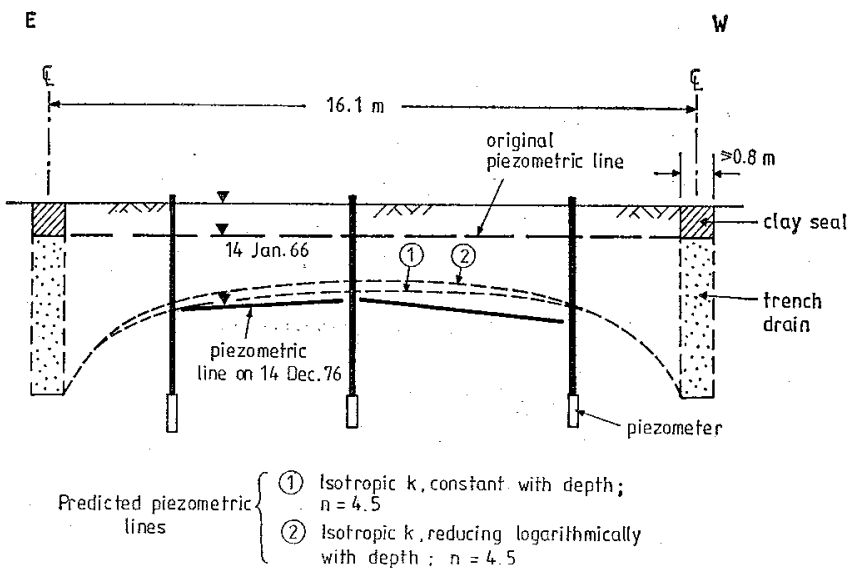

Fig. 26. Cross section of trench drains at Guildford, south. ern England, comparing predicted long-term piezometric levels with those measured 10.5 years after installation of drains (after Hutchinson 1977).

and $25 \mathrm{~m}$ below mean sea level and the lowest level at which drainage galleries can conveniently discharge by gravity is near the top of the wall at about $6.5 \mathrm{~m}$ above mean sea level, a few metres above high tide level (Toms 1953). The galleries have thus had to be driven within the slipped masses (Fig. 27). The first system of such galleries was completely destroyed by the major landslide of 1915. They were subsequently reconstructed at the same levels and are still operating.

More commonly, drainage galleries are driven, with sufficient cover and with due regard to the hydrogeology, in sound, in situ rock beneath the base of a landslide. Such galleries can also play a valuable role in site investigation. From this secure position, fans of upward-directed, small diameter drainage holes may then be drilled through the roof of the gallery to extend its influence. An example of such a measure, constructed beneath a moving tip of coal mine waste at the National Colliery, south Wales, is illustrated in Fig. 28 (data by courtesy of the National Coal Board and Sir William Halcrow \& Partners).

A variant of this technique is currently under construction as part of the stabilization works for the Taren slip, south Wales (Fig. 29). In order to make the earliest possible start on reducing groundwater pressures in the body of the slip, wells of $300 \mathrm{~mm}$ inside diameter are being installed on a line through the area of highest piezometric levels and will be pumped by electric submersible pumps during the period of toe berm and drainage gallery construction. Eventually the drainage gallery (rectangular base $2.3 \mathrm{~m}$ wide with a semicircular roof giving a maximum height of $2.55 \mathrm{~m}$ ), driven at a rising gradient of $5 \%$ within the in situ strata beneath the slide, will connect into the bottoms of all these wells, converting them to permanent gravity drainage (data by courtesy of the Welsh Office, Director of Engineering (Transport and Highways) and Rendel, Palmer \& Tritton).

A theoretical study of the optimum locations of drainage galleries running at right angles to the plane of slope cross sections has been made by Sharp (1970), for various values of $R_{k}$. A more general discussion is provided by Sharp, et al. (1972).

iv. groundwater at intermediate depths

Drainage can be difficult to achieve economically where the groundwater is too deep to be reached by ordinary trench drains and where also the scale and importance of the slide is too small to justify a drainage gallery. In such cases, especially on slopes that are of not too low an 


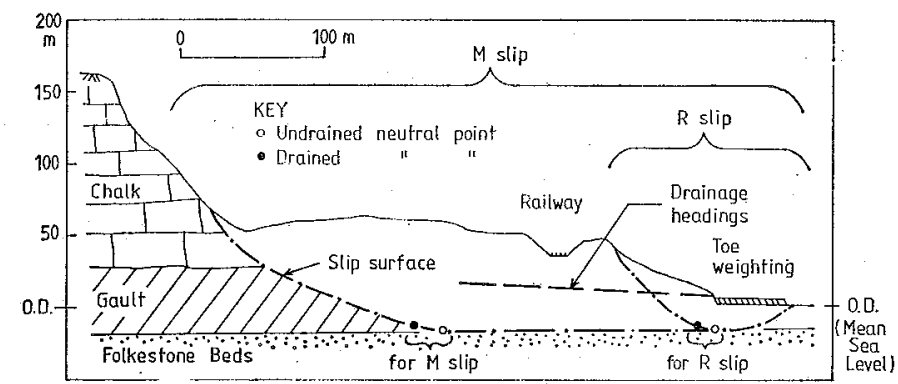

Fig. 27. Outline cross-section of the multiple rotational landslides on the south coast of England at Folkestone Warren, Kent, showing the positions of the toe weighting and the drainage headings (after Hutchinson, et al. 1980).

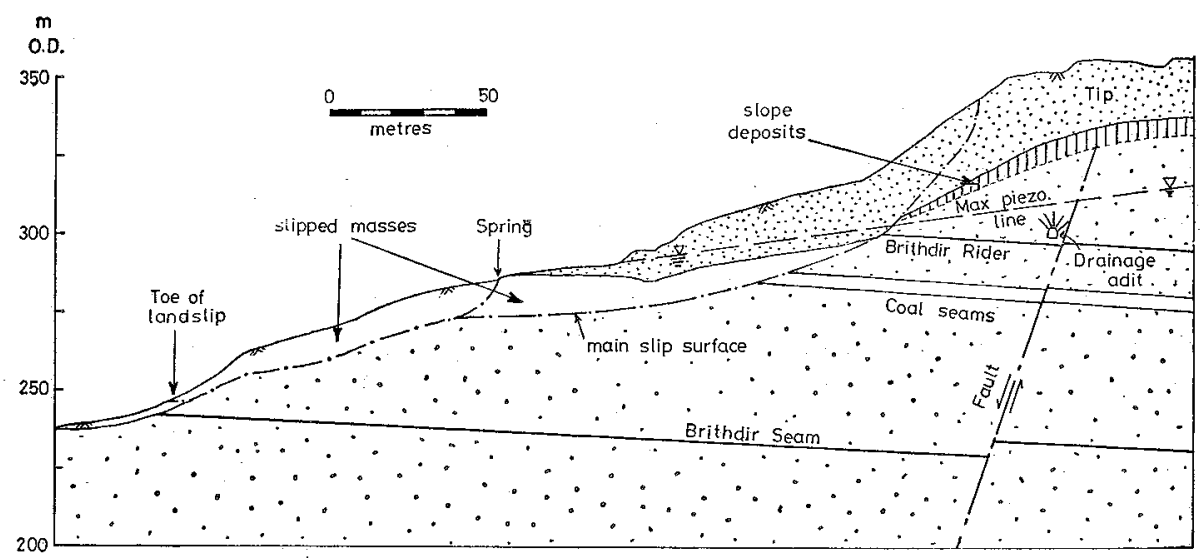

Fig. 28. Cross-section of the natural slope and tip of coal-mine waste at National Colliery, south Wales. The drainage adit is approximately $730 \mathrm{~m}$ long and the radial drainage holes are between $3 \mathrm{~m}$ and $6 \mathrm{~m}$ in length. The total discharge in wet weather exceeds 100 litres/sec. (Acknowledgements to the National Coal Board and to Sir William Halcrow and Partners).

inclination, bored sub-horizontal drains may constitute an appropriate solution. Such drains are not widely used in Britain, despite the success of an experimental layout installed in a slow moving landslide at Otley, Yorkshire, in 1964-67 (Robinson 1967, Hutchinson 1977). Sub-horizontal drains generally need to be provided with filters and they are probably most effective when they can intersect one or more permeable, water-bearing horizons.

An alternative approach, particularly suitable where the front part of the slope is steep, is to install bored, sub-horizontal drains from just above the slope foot and then to sink vertical drainage shafts of modest diameter (typically 1.0 to $1.5 \mathrm{~m}$ ) in the rearward parts of the landslide to meet these. The sub-horizontal drains then provide gravity discharge for the vertical drains. This system of drainage has been used in the stabilization of London Clay cliffs at Clacton-onsea, Essex, and of a high retaining wall near Euston Station, London. A further technique, widely used in Japan, consists of sinking a shaft in the landslide from which radiating, subhorizontal drains can be bored as required to bring about the necessary groundwater lowering. This method, has been used effectively in the Beacon Hill landslide in London Clay at Herne Bay, Kent (Fig. 30). Four $4 \mathrm{~m}$ diameter, $14 \mathrm{~m}$ deep shafts were constructed, from which 100 $\mathrm{mm}$ diameter radial drain holes were drilled and lined with porous land drains. Slide movements, which had amounted to $13 \mathrm{~mm}$ in the year prior to drainage, fell to $6 \mathrm{~mm} /$ year in the first year 
after completion of the works and then ceased. As about $75 \%$ of the slip surface is located below high tide level, it was necessary to install a permanent automatic pumping system to discharge the water collected in the shafts. The improvement in factor of safety produced by the drainage was calculated to be $30 \%$ (Thorn \& Roberts 1981: other data by courtesy of $\mathrm{Mr}$ B.E. Hardy, City Engineer, Canterbury City Council).

\section{Profile Changes by Cutting and Filling}

It is instructive to study the effects of cuts and fills on a landslide by applying the influence line concept, familiar from structural engineering. A fill may be simulated by a downward influence load, a cut by an upward one. *

An unstable or potentially unstable slope, with a fixed slip surface of general shape, is represented two-di-

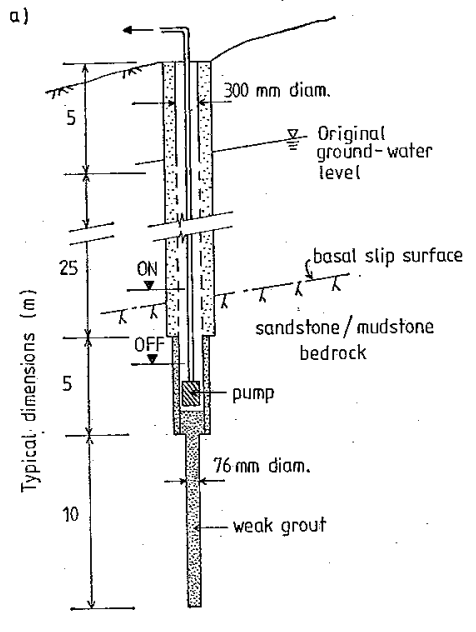

NOT TO SCALE

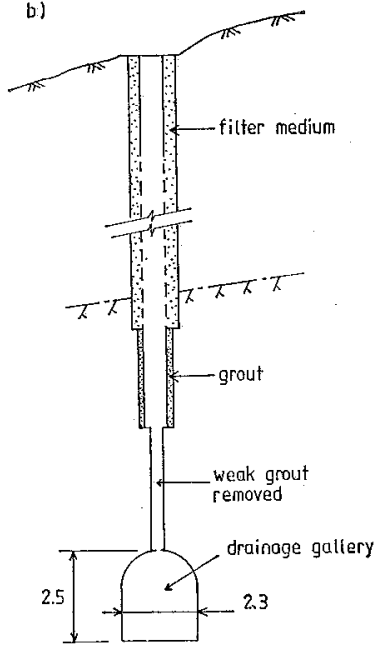

Fig. 29. Sectional elevations of the pump/tube wells used as part of the stabilization measures at the Taren landslide, Taff Vale, south Wales. a) Initial mode of operation; b) Final mode of operation. (AcknowIedgements to the Director of Engineering (Transport and Highways), Welsh Office and to Rendel Palmer and Tritton).

mensionally by the cross-section of Fig. 31a. A convenient, arbitrary influence load, $\Delta W$, taken here as positive to represent a fill, is assumed to act, in turn, at successive positions between the head and the toe of a postulated or actual slip surface. The ratio

[1] $\frac{F_{1}}{F_{0}}=\frac{F_{0}+\Delta F}{F_{0}}=\frac{\text { overall } F \text { with } \Delta W \text { acting }}{\text { original value of } F}$

is taken as a measure of the effect of the influence loading on the overall factor of safety on that particular slip surface. Influence lines in terms of $F_{1} / F_{0}$ can then be obtained (Fig. 31b) for undrained, intermediate or drained conditions with respect to the influence load. The position on a cross-section where $F_{1} / F_{0}=1.0$, at which an influence load will have no effect on $F_{0}$, is termed a "Neutral Point".

The Neutral Point positions can be obtained, as above, by constructing the appropriate influence

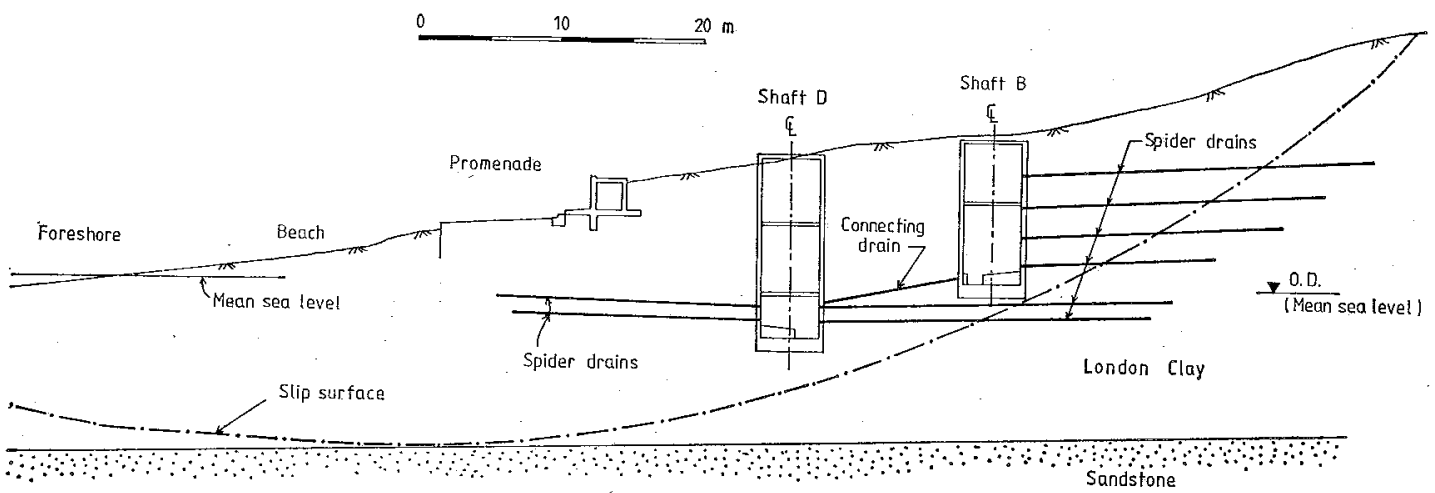

Fig. 30. Cross-section of the Beacon Hill landslide in London Clay coastal slopes at Herne Bay, southern England, showing drainage measures used for its stabilization. (Acknowledgements to Mr B.E. Hardy, City Engineer, Canterbury City Council).

* The concept may also be applied to drainage (Hutchinson 1977), and to inclined loading by deep anchors. 
lines or, more directly, in the manner given in the Appendix (Hutchinson 1977, 1984). The influence load for a fill, for example, may be conveniently represented by a uniformly distributed load of incensity $w$ per unit horizontal area, acting on a slice $i$ of horizontal width $b$ (Fig. 31a). Thus $\Delta W=w b$. The application of this load is considered to set up undrained pore-water pressures of magnitude $\Delta u=\bar{B} \cdot \Delta \sigma_{1} \simeq \bar{B} w$ on the subadjacent slip surface, which is inclined at an angle $\alpha_{i}$ to the horizontal. By applying a suitable, effective stress method of stability analysis, the following equation defining the Neutral Point positions is derived (see Appendix):

[6] $\tan \alpha_{n}=\left(1-\bar{B} \sec ^{2} \alpha_{n}\right) \frac{\tan \phi^{\prime}}{F_{0}}$

where $\alpha_{n}$ is the inclination of the slip surface at the Neutral Point.

It will be noted, from Equation [6], that the positions of the Neutral Points for a given slip surface are independent of the values of $c^{\prime}$ and $\Delta W$.

Two special cases of Equation [6] are of particular interest (Fig. 31):

(a) when $\bar{B}=1.0$, corresponding to fully undrained conditions with respect to the influence load in saturated material, $\alpha_{n}=0$. Hence the related "Undrained Neutral Point, $N_{u}$ " is. located where a tangent to the slip surface is horizontal.

(b) when $\bar{B}=0$. Although $\bar{B}$ is an undrained parameter, $\vec{B}=0$ may conveniently be regarded also as equivalent to fully drained conditions with respect to the influence load. Hence the "Drained Neutral Point, $N_{d}$ ", is located where the slip surface is inclined valleywards at $\phi_{\text {mob', }}^{\prime}$ where

[15] $\phi^{\prime}{ }_{\text {mob }}=\tan ^{-1}\left(\frac{\tan \phi^{\prime}}{F_{0}}\right)$

For circular slip surfaces, the above conclusions are evident from the statics of the friction circle and are touched upon, for the drained, circular case, in the early work of Petterson, summarized in his 1955 paper.

In cases where $1.0>\vec{B}>0$, the Neutral Points will occupy positions " $N_{i}$ " intermediate between those of cases (a) and (b) above, as defined by Equation [6]. These cases may again be conveniently regarded as either undrained, with $1.0>\bar{B}>0$, or as equivalent to partly drained situations with corresponding porewater pressures.

The positions of Neutral Points defined by Equation [6] have been checked, for cuts and fills and for various shapes of slip surface, by computing the full influence lines. The Bishop Simplified (Bishop 1954) and Morgenstern and Price (1965) methods of stability analysis were used for circular and non-circular slip surfaces, respectively. The agreement in all cases is excellent (Hutchinson 1977).

In cases where the positions of Neutral Points are defined on more than one section of a landslide, the traces of these may be drawn in plan to form "Neutral Lines", as in Fig. 31c. Applications of these concepts are discussed below.

The foregoing treatment presupposes the existence

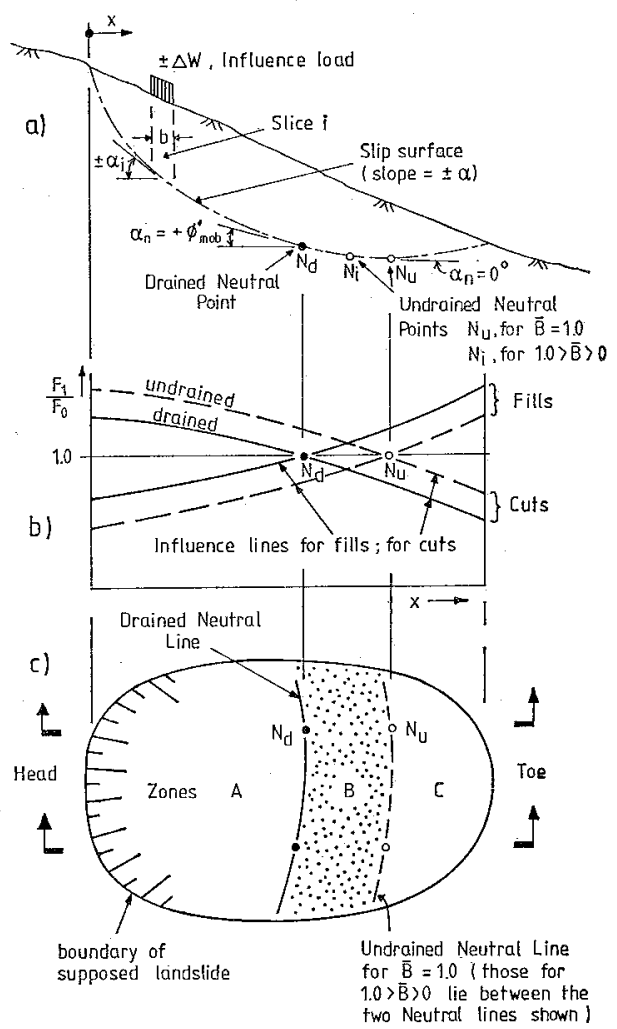

Fig. 31. Influence loads, influence lines, Neutral Points and Neutral Lines.

a) Section of a landslide, with influence load acting.

b) Undrained and drained influence lines (diagrammatic) for cuts and fills.

c) Plan, with Undrained and Drained Neutral Lines and zones A to C. (After Hutchinson 1977, 19 84). 
of a given, failure surface which remains in the same position during the application of the influence loads and those associated with the eventual stabilizing measures. In principle, however, the critical slip surface for a loaded slope will tend to differ from that for the unloaded one. This characteristic may seriously limit the applicability of the above concepts to firsttime failures, unless the possible positions of the slip surface are closely constrained by geological, or other factors. In the case of slides on pre-existing failure surfaces, on the other hand, the likelihood of a significant shift in slip surface position with loading is smaller, particularly in materials which exhibit a marked drop from intact strength to residual, and these concepts can be most useful. Even in such cases, though, the possibility of other, generally pre-existing, slip surfaces being present and becoming critical must be carefully considered and guarded against, for example to prevent over-riding or under-thrusting of a toe fill.

With the foregoing provisos, influence lines in terms of $F_{1} / F_{0}$, for positive or negative vertical loading and for undrained and drained conditions with respect to the influence load (Fig. 31b) provide an immediate, quantitative indication of the most effective location and distribution of corrective cuts or fills and of the effects of changing the unit weight of any part of the slide mass, either notionally or in practice. The optimum geometry of corrective earthworks will also, of course, be influenced by environmental, surface drainage and other considerations. Influence lines of the type discussed may also be used to determine the total improvement in $F_{0}$ produced by proposed earthworks, but this may be more conveniently done by orthodox methods.

As mentioned, given two or more sections for which the position of the Neutral Points have been determined, the corresponding Neutral Lines may be drawn in plan. * Representative Neutral Lines, for a single landslide, are illustrated in Fig. 31c. In plan, the slide is divided by the Undrained and Drained Neutral Lines into three zones, A, B and C. The effects on the original factor of safety of the slide, $F_{0}$, of fills and cuts in these various zones are as follows:
A fill in $\left\{\right.$ Zone $B$ will reduce $F_{0}$ in the short-term but increase it in the long-term. Zone $\mathrm{C}$ will increase $F_{0}$ in both the short-and long-term.
Zone A will reduce $F_{0}$ in both the short-and long-term
$\mathrm{A}$ cut in $\left\{\begin{array}{l}\text { Zone } \mathrm{A} \text { will increase } F_{0} \text { in both the short-and long-term. } \\ \text { Zone } \mathrm{B} \text { will increase } F_{0} \text { in the short-term but reduce it in the long-term. } \\ \text { Zone } \mathrm{C} \text { will reduce } F_{0} \text { in both the short-and long-term. }\end{array}\right.$

It is of considerable value to have zoned an actual or potential landslide in this manner, particularly in the preliminary planning of stabilization works or in exploring the best route for a road or railway across the slide. In the case of fills, for example, these should ideally be located downslope of the Undrained Neutral Line for the appropriate value of $\bar{B}$ (generally $<1.0$ in practice). If this is not practicable, every effort should be made to keep fills downslope of the Drained Neutral Line. It is obviously not impossible to place fills upslope of this line, but to do so will add very considerably to the difficulties and cost of achieving satisfactory stability.

The best known British example of stabilization of a landslide by loading its toe is Folkestone Warren (Fig. 27), where the present toe-weighting structure was constructed on the foreshore in 1948-54 (Viner Brady 1955). Currently, a similar measure is being taken to stabilize a coastal landslide at Llanddulas, crossed by the new north Welsh coast road. The construction there of a trial embankment on the foreshore is described by Wilson and Smith (1983). An outline section of the completed toe weighting is given in Fig. 32. Inland, toe fills were used as part of the stabilization works for the Walton's Wood slide (Early and Skempton 1974). A major fill of this type is being constructed across the toe of the Taren slip in south Wales. In the latter two cases, toe loading is supplemented by surface and sub-surface drainage works.

It is argued by Hutchinson (1984) that fills at the toe of a slide are preferable to cuts at its head. Also, that in complex slides, with several interconnected slip surfaces, fills or cuts should

\footnotetext{
* Clearly, for non-circular slip surfaces embodying a planar section, the Neutral Line will widen to form a "Neutral Zone" should the slope of the planar part of the slip surface coincide with the value of $\alpha_{n}$ for the particular conditions obtaining.
} 
be confined to the extreme toe and extreme head of the slides, respectively. In intermediate positions, while they will improve the stability of one part of the complex, they will decrease that of another.

Slope flattening by excavation is commonly considered to be a safe way of improving stability. Consider the situation shown in Fig. 33. A cutting has been made over-steep and has developed shallow slides on its faces. The engineers responsible decide to flatten the cutting slope by excavation to cure these shallow slides. As shown, this operation succeeds in its aim, but triggers a much larger deep-seated slide, of which the engineers were unaware, because most of the unloading resulting from the slope flattening is downslope of the Drained Neutral Point of the deepseated slide (Hutchinson 1983). A full-scale example of such an event is provided by the pre-existing, non-circular, Cliff House landslide of 1962, at Lyme Regis, Dorset, in Liassic clays. This suffered a renewal of movement immediately after the completion of slope flattening in the area of its toe (Hutchinson, 1984).

In the above examples, the slope flattening was done artificially. It is also possible for this to occur naturally, by rock falls from the steep front faces of slides. The resulting sudden drop in factor of safety can provide a natural mechanism for accelerating the slide (Hutchinson, 1984).

\section{Replacement of a Weak Slip Surface by Stronger Material}

As mentioned above, one of the benefits of a counterfort drain is that, over the plan area of the drain, a slip surface with a residual value of perhaps only 10 or $12^{\circ}$ is replaced by a granular fill with a $\phi^{\prime}$ of 35 to $40^{\circ}$. This can provide a useful increase in factor of safety, which is secure against drain clogging.

This principle has been used in road construction on clayey solifluction sheets in Kent overlying Gault clay in Cambridgeshire (Dr A.G. Weeks, pers. comm.). As the basal slip surfaces in the solifluction debris were only at 1.5 to $2.5 \mathrm{~m}$ depth, they were readily dug out beneath the downslope batter of road embankments on sidelong ground and replaced either by the excavated clayey debris, remoulded to destroy the contained slip surfaces, or by granular fill, as necessary.

Under this general heading, mention might also be made of the stabilization of landslides by so-called "claquage" grouting, in which cement grout is injected into the slip surface so that its two sides eventually become separated by a few centimetres of hardened grout (Ayres 1961).

\section{Anchors, Restraining Structures and Bridging Structures}

The use of anchors in rock slope stabilization may be illustrated by reference to a $20 \mathrm{~m}$ high Chalk cliff at Kingsgate, Kent, near the fall at Joss Bay which has been mentioned previously. This was stabilized by installing six rows of anchors, consisting of $28.6 \mathrm{~mm}$ diameter high tensile steel bars, with working loads ranging from 167 to $265 \mathrm{kN}$ and fixed anchor lengths of between 5 and $8 \mathrm{~m}$ (Fig. 34). Restressing carried out 1.1 years after installation showed that the loss of

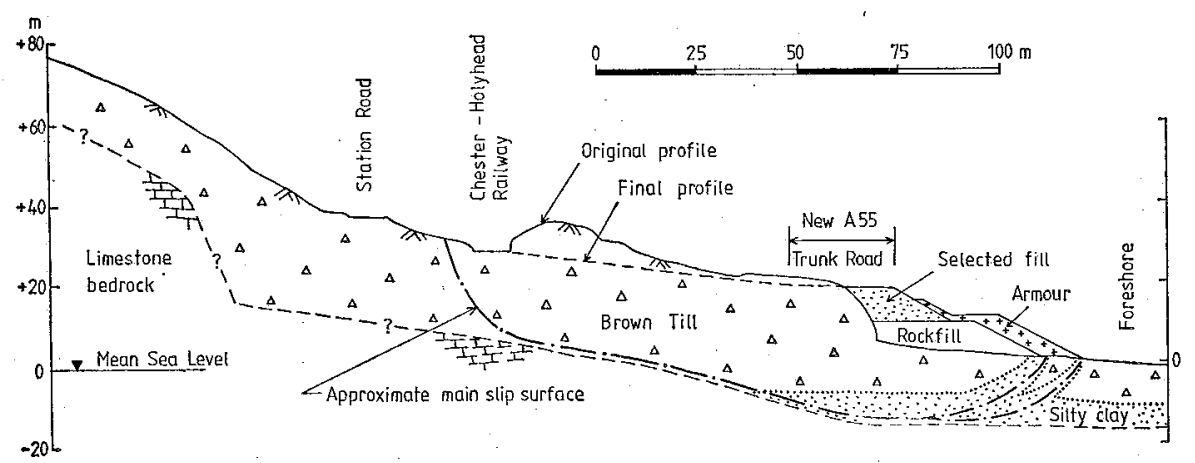

Fig. 32. Cross-section of coastal landslide at Llanddulas, north Wales, at chainage $1,440 \mathrm{~m}$, showing toe weighting. (Acknowledgements to the Director of Engineering (Transport and Highways), Welsh Office and to R. Travers Morgan and Partners). 

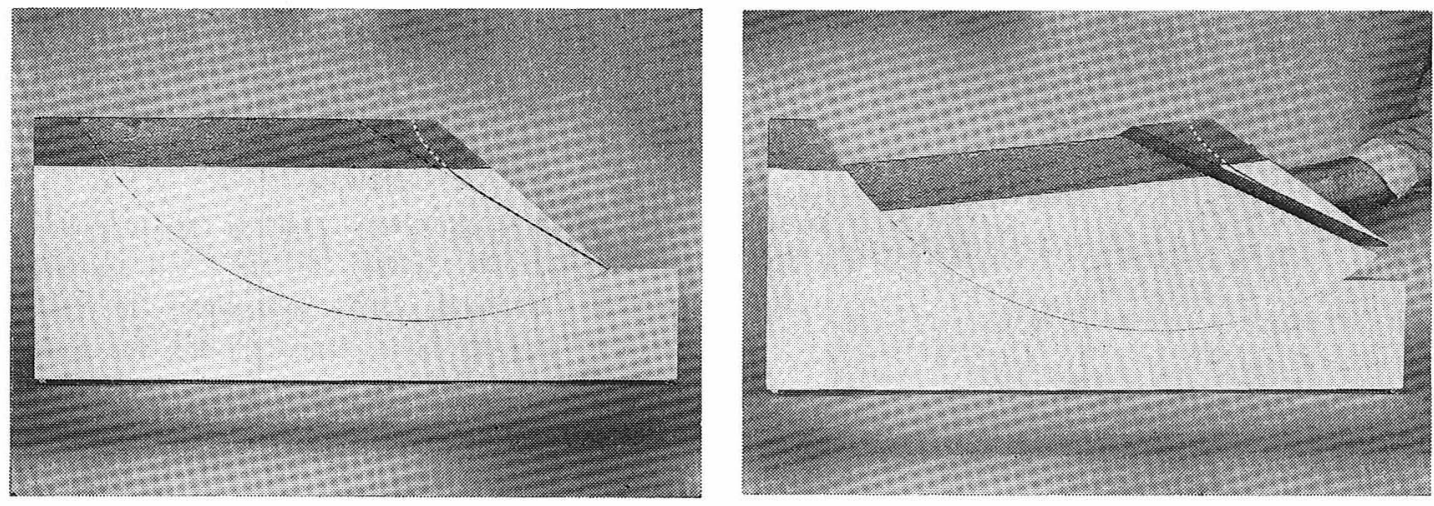

Fig. 33. Model showing:

a) shallow slide in a cutting above a pre-existing, deep-seated circular slip surface,

b) how remedying the shallow slide by flattening the cutting slope (by excavation) causes reactivation of the deep-seated slide. (After Hutchinson 1983, 1984: photographs by Miss Joyce Gurr).

prestress in these anchors increased with the degree of weathering of the Chalk, reaching a maximum of $16 \%$ in the upper row of anchors (Hutchinson 1970).

Stabilization by deep, pre-stressed anchors is being applied increasingly to soil slopes. A recent example is provided by the stabilization of a landslide in glacial and glacio-fluvial deposits which was affecting the Taff Vale Trunk Road at Nantgarw, south Wales (Fig. 35). Prior to treatment in 1980, movements of up to $15 \mathrm{~mm}$ /year were occurring in places at the head of the slide and of 2 to $5 \mathrm{~mm} /$ year at its toe. Largely because of the severe spatial constraints, anchoring into the underlying Coal Measures bedrock proved to be the most suitable stabilization measure. In all, 128 strand anchors inclined at between 25 and $30^{\circ}$ to the horizontal, each with $500 \mathrm{kN}$ working load, were installed through 32 reinforced concrete anchor pads (each $3 \mathrm{~m}$ high $\times 4.8 \mathrm{~m}$ broad). Losses of anchor stress occurring as a result of pad settlement, and anchor relaxation, have been moderate and have been made up by occasional restressing (information by courtesy of the Director of Engineering (Transport and Highways), Welsh Office, and Rendel Palmer and Tritton).

General treatments of anchoring practice in the U.K. are given by Hanna (1982) and by Littlejohn (1970, 1980).

Cantilever sheet pile walls constitute a rapidly constructed countermeasure which has its application chiefly to slips of small to moderate size in railway cuttings (Toms and Bartlett 19 62). Where more time is available, such slips, as well as larger ones, may be stabilized by the construction of walls of closely spaced, or contiguous, bored reinforced concrete piles, of either cantilevered or anchored type. A general discussion of this type of structure is given by NorthLewis and Lyons (1975).

Bridging of landslides is rare in Britain. It was used recently, however, near Llanhilleth, in the Ebbw Vale, south Wales. A new road had to be taken across a shallow and slow-moving translational slide in glacial lake sediments, mentioned earlier. After exploring several different designs, it was decided that the best solution consisted of carrying the road across the slip toe on a viaduct supported on narrow piers at about $30 \mathrm{~m}$ centres (Fig. 36). The piers are anchored to the underlying rock and are capable of resisting passive earth pressures should these develop locally (data by courtesy of the County Engineer and Surveyor, Gwent County Council).

\section{Seepage Erosion and its Countermeasures}

While not in itself strictly a type of landslide, seepage erosion is often a potent factor in producing a variety of slope failures. It comprises the removal of grains of soil, usually fine sand, by groundwater seepage at a free face. The eroding surface then migrates or "back-saps" into the slope, often as a two-dimensional slot rather than as a pipe. Hence the superincumbent strata 


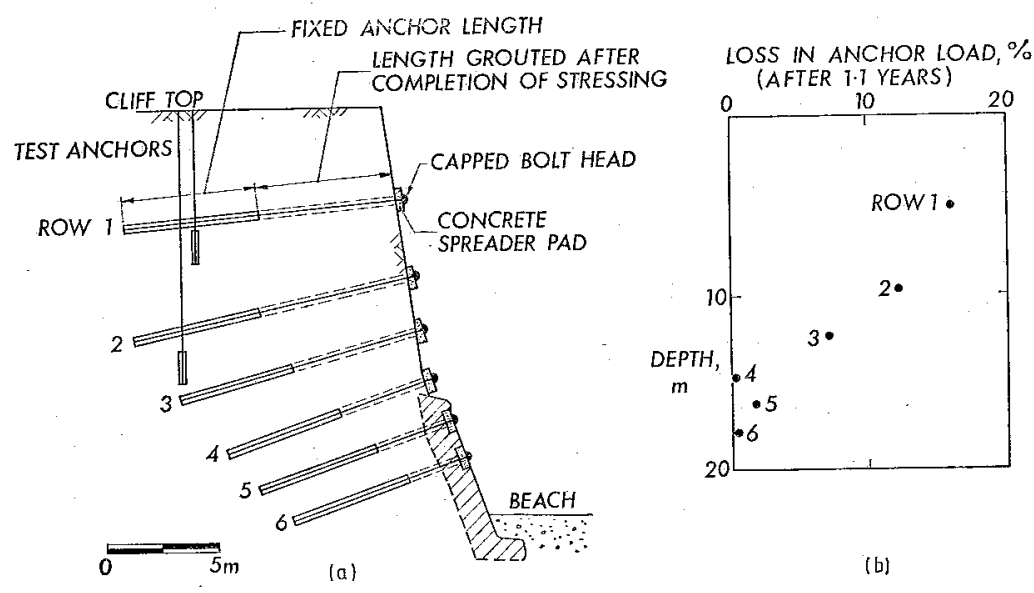

Fig. 34. Stabilization of a Chalk cliff at Kingsgate Castle, near Joss Bay, southern England, by rock anchoring: a) cross-section; b) measured anchor losses after 1.1 years (after Hutchinson 1970).

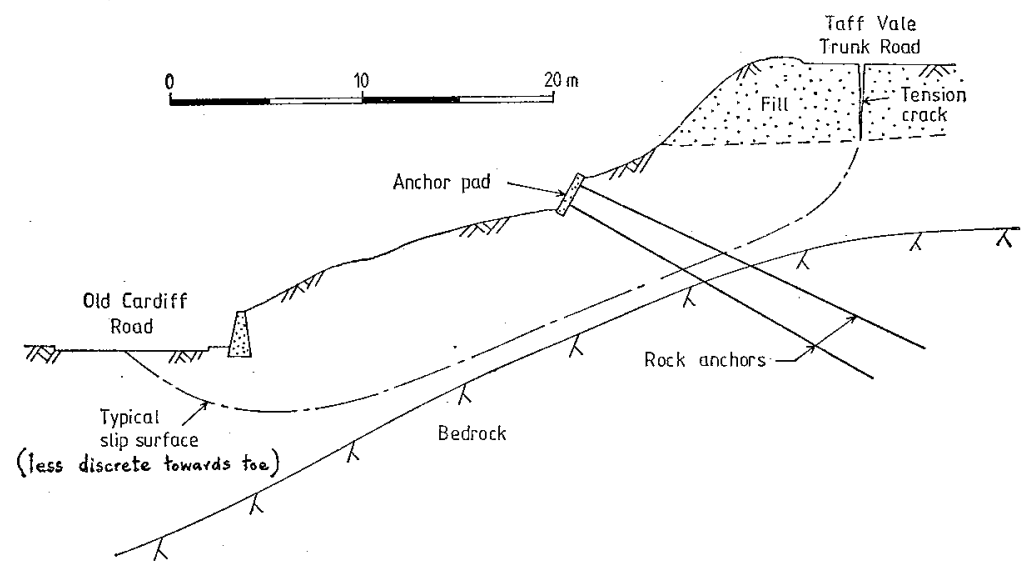

Fig. 35. Cross-section of landslide in Quaternary deposits at Nantgarw, south Wales, stabilized by deep anchoring. (Acknowledgements to the Director of Engineering (Transport and Highways), Welsh Office and to Rendel Palmer and Tritton).

are undermined and eventually collapse. Depending on the geological setting, failures ranging from rock-falls to mudslides may result (Hutchinson 1968, 1982).

A well-documented case record of this type of failure, involving the alternating fine to medium sand and clay layers of the Tertiary Woolwich and Reading Beds at Newhaven, Sussex, is provided by Ward (1948). Seepage erosion in a sand layer there led to the development of extensive mudslides, which extended back from the cliff edge for over $90 \mathrm{~m}$ at an average slope of around $5^{\circ}$. A further case on the coast of southern England, at Chale in the Isle of Wight, is reported by Hutchinson et al. (1981). There the seepage erosion is occurring within fine sands of the Lower Cretaceous, Lower Greensand Series and is a major factor in bringing about active destruction of the cliffs.

The usual countermeasure for seepage erosion is to place an appropriately designed filter layer directly on the face of the eroding stratum. This was done, for example, in the case at Newhaven, quoted above, where a trench several metres deep, excavated in short lengths, was required to gain access to the eroding fine sand (Ward 1948). Alternatively, it may be feasible to arrest seepage erosion by draining away the groundwater which is causing. it. This was done at Bournemouth, Hampshire, (Fig. 37) where the perched groundwater concerned was drained by 
a double row of vertical sand drains located 15 to 25 $m$ behind the unstable cliff face of Eocene sands and clays (Anon 1965).

\section{ACKNOWLEDGEMENTS}

The Author is very grateful to UNESCO, for arranging his visit to Japan, and to The Japan Society of Landslide, The Japanese Geotechnical Society and the Japanese Sabo Society for inviting him to present this paper in Tokyo and Osaka in the summer of 1983. He would also like to thank many colleagues in the U.K. for providing information for the paper.

\section{REFERENCES}

ANON. (1951). Sussex County Mag., 25, 441.

ANON. (1965). Cliff stabilization scheme. East Cliff, Bournemouth being protected with sand drains. Surveyor and Municipal Engr, 125, 25.

AYRES, D. J. (1961). The treatment of unstable slopes and railway track formations. Jl and Trans. Soc. of Engrs., 52, $111-138$.

BISHOP, A.W. (1954). The use of the slip circle in the stability analysis of slopes. Proc. European Conf. on Stability of Earth Slopes, Stockholm, 1, 1-13. Reprinted (1955) in: Géotechnique, 5, 7-17.

BISHOP, A.W. (1973). The stability of tips and spoil heaps. Quarterly Jl. Engrg. Geol., 6, 335-376.

BROMHEAD, E. N. (1978). Large landslides in the London

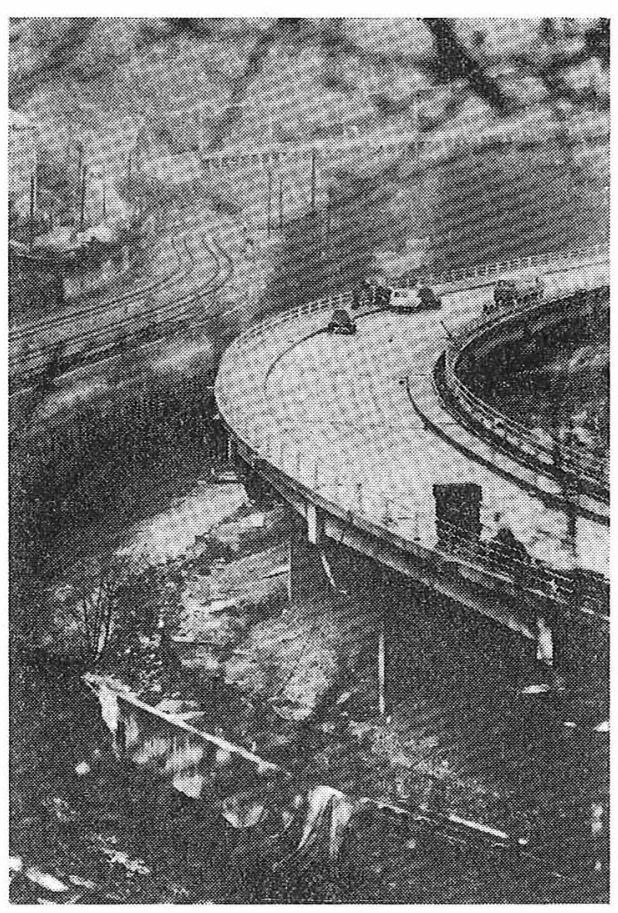

Fig. 36. Bridging of a translational landslide on the west bank of the River Ebbw at Llanhilleth, south Wales. (Acknowledgements to Gwent County Council and to The New Civil Engineer). Clay at Herne Bay, Kent. Quarterly Jl. Engng. Geol.,

11, 291-304.
CHANDLER, R. J. (1977). Backanalysis techniques for slope stabilization works: a case record. Géotechnique, 27, $479-495$.

CONWAY, B. W. (1974). The Black Ven landslip, Charmouth, Dorset. Rep. Inst. Geol. Sci., No. $74 / 3$. $16 \mathrm{pp}$.

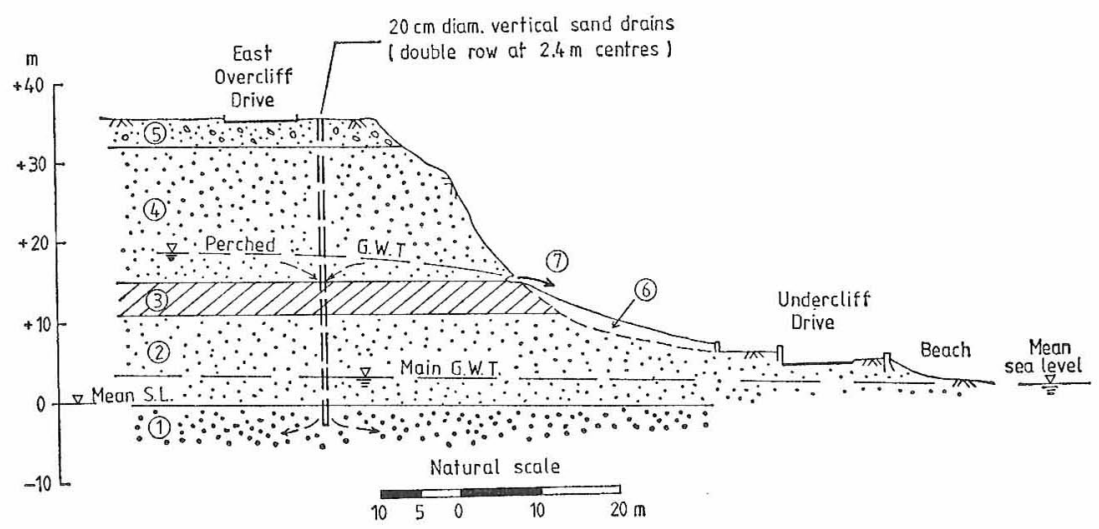

Fig. 37. Cross-section of East Cliff, Bournemouth, southern England. $1=$ coarse sand; $2=$ silty fine to medium sands; $3=$ clays and sandy clays; $4=$ fine to medium sands; $5=$ sandy gravel; $6=$ slide debris and outwash; $7=$ horizon of seepage erosion and backsapping. Subsequent remedial measures are indicated by broken lines (after Hutchinson 1982). 
DE FREITAS, M. and WATTERS, R. (1973). Some field examples of toppling failure. Géotechnique, 23, 495-513.

EARLY, K. R. and SKEMPTON, A. W. (1972). Investigation of the landslide at Walton's Wood, Staffordshire. Quarterly Jl. Engrg. Geol., 5, 19-41.

EVANS, R.S. (1981). An analysis of secondary toppling rock failures-the stress redistribution method. Quarterly Jl. Engng. Geol., 14, 77-86.

HANNA, T.G. (1982). Foundations in Tension-Ground Anchors. Trans. Tech. Publications, ClausthalZellerfield.

HENKEL, D. J. (1961). Slide movements on an inclined clay layer in the Avon Gorge in Bristol. Proc. 5th Int. Conf. Soil Mech. and Foundn. Engng., Paris, 2, 619-624.

HENKEL, D. J. and SKEMPTON, A.W. (1954). A landslide at Jackfield, Shropshire, in an over-consolidated clay. Proc. European Conf. Stability of Earth Slopes, Stockholm, 1, 90-101. (Reprinted in Géotechnique, 5, 131-137, 1955).

HOEK, E. and BRAY, J. (1977). Rock slope engineering (2nd edn). The Institution of Mining and Metallurgy, London.

HORSWILL, P. and HORTON, A. (1976). Cambering and valley bulging in the Gwash valley at Empingham, Rutland. Phil. Trans. Royal Soc. Lond. A283, 427-462.

HUTCHINSON, J. N. (1967). The free degradation of London Clay cliffs. Proc. Geotechn. Conf., Oslo, 1, 113-118.

HUTCHINSON, J. N. (1968). Mass movement. In Encyclopedia of Geomorphology (ed. R. W. Fairbridge), 688-696. Reinhold Book Corpn, New York, Amsterdam, London.

HUTCHINSON, J. N. (1970). Discussion on Littlejohn (1970). Ground Engineering, Proceedings of Conf., 84-86. Instn of Civil Engrs, London.

HUTCHINSON, J.N. (1972). Fields and Laboratory studies of a fall in Upper Chalk cliffs at Joss Bay, Isle of Thanet. Stress strain behaviour of soils (ed. R. H. G. Parry). Proc. Roscoe Memorial Symp., Cambridge, 692-706. G. T. Foulis \& Co. Ltd., Henley-on-Thames.

HUTCHINSON, J.N. (1973). The response of London Clay cliffs to differing rates of toe erosion. Geologia applicata e idrogeologia, 8, 221-239.

HUTCHINSON, J. N. (1976). Coastal landslides in cliffs of Pleistocene deposits between Cromer and Overstrand, Norfolk, England. Laurits Bjerrum Memorial Volume, 155-182. Norwegian Geotechnical Institute, Oslo.

HUTCHINSON, J. N. (1977). Assessment of the effectiveness of corrective measures in relation to geological conditions and types of slope movement. Symposium on Landslides and other Mass Movements, Prague. Bull. Int. Assoc. of Engrg. Geol., No. 16, 131-155. (Reprinted in Norwegian Geotechnical Inst. Pub., Nr. 124, 1-25, 1978).

HUTCHINSON, J.N. (1980). Various forms of cliff instability arising from coast erosion in the U.K. Fjellsprengningsteknikk-Bergmekanikk-Geoteknikk 1979, 19.1-19.32. Trondheim, Tapir for Norsk Jord-og Fjellteknisk Forbund tillknyttet NIF.

HUTCHINSON, J. N. (1982). Damage to slopes produced by seepage erosion in sands. Landslides and Mudflows. Reports of Alma-Ata International Seminar October 1981 (ed. A. Sheko), 250-268. Centre of International Projects, GKNT, Moscow.

HUTCHINSON, J.N. (1983). Engineering in a landscape. Inaugural Lecture, 9th October 1979. Imperial College of Science and Technology, University of London.

HUTCHINSON, J.N. (1984). An influence line approach to the stabilization of slopes by cuts and fills. Canadian Geotech. $J l$. (in press).

HUTCHINSON, J. N. and BHANDARI, R.K. (1971). Undrained loading, a fundamental mechanism of mudflows and other mass movements. Géotechnique, 21, 353-358.

HUTCHINSON, J.N., BROMHEAD, E. N. and LUPINI, J.F. (1980). Additional observations on the landslides at Folkestone Warren. Quarterly Jl. Engng Geol., 13, 1-31.

HUTCHINSON, J. N., CHANDLER, M. P. and BROMHEAD, E.N. (1981). Cliff recession on the Isle of Wight SW coast. Proc. 10th Int. Conf. Soil Mech. and Foundn Engrg., Stockholm, 1, 429-434.

HUTCHINSON, J.N. and GOSTELOW, T.P. (1976). The development of an abandoned cliff in London Clay at Hadleigh, Essex. Phil. Trans. Royal Soc. Lond., A283, 557-604.

HUTCHINSON, P. O. (1893). Landslip at Sidmouth. Repts and Trans Devonshire Assoc., 25, 174-175.

LITTLEJOHN, G. S. (1970). Soil anchors. Ground Engineering, Proceedings of Conf., 33-44. The Instn of Civil Engrs, London.

LITTLEJOHN, G.S. (1980). Design estimation of the ultimate carrying capacity of ground anchors. Ground 
Engineering, 13, 25-39.

MORGENSTERN, N.R. and PRICE, V.E. (1965). The analysis of the stability of general slip surfaces. Géotechnique, 15, 79-93.

NORTH-LEWIS, J.P. and LYONS, G.H.A. (1975). Contiguous bored piles. Proc. Conf. on Diaphragm Walls and Anchorages, Instn Civil Engrs, London, 189-194.

PETTERSON, K.E. (1955). The early history of circular-cylindrical sliding surfaces. Géotechnique, 5, 275296.

PITTS, J. (1979). Morphological mapping in the Axmouth-Lyme Regis Undercliffs. Quarterly Jl. Engng Geol., 12, 205-217.

ROBINSON, B. (1967). Landslip stabilization by horizontally bored drains. Highways and Public Works, 35 , $32-33,35$ and 37.

SHARP, J.C. (1970). Drainage characteristics of subsurface galleries. Proc. 2nd Congress Int. Soc. Rock Mech., Belgrade, 3, 197-204.

SHARP, J.C., HOEK, E. and BRAWNER, C. O. (1972). Influence of groundwater on the stability of rock masses-drainage systems for increasing the stability of slopes. Trans Inst. Mining and Metallurgy, London (Section A), 81, 113-120.

SKEMPTON, A. W. (1977). Stability of cuttings in brown London Clay. Proc. 9th Int. Conf. Soil Mech. and Foundn Engrg, Tokyo, 3, 361-270.

SKEMPTON, A.W. and HUTCHINSON, J. N. (1969). Stability of natural slopes and embankment foundations. Proc. 7th Int. Conf. Soil Mech. and Foundn Engrg, Mexico, State-of-the-Art Vol, 291-340.

SKEMPTON, A. W. and WEEKS, A. G. (1976). The Quaternary history of the Lower Greensand escarpment and Weald Clay vale near Sevenoaks, Kent. Phil. Trans Royal Soc. Lond., A283, 493-526.

SMILES, S. (1862). Lives of the Engineers (3 vols). John Murray, London.

STEPHENS, N., CREIGHTON, J.R. and HANNON, M. A., (1975). The Late Pleistocene period in northeast Ireland: an assessment 1975. Irish Geography, 8, 1-23.

THORN, R.B. and ROBERTS, A. G. (1981). Sea defence and coast protection works. Thomas Telford Ltd, London.

TOMS, A.H. (1953). Recent research into the coastal landslides at Folkestone Warren, Kent, England. Proc. 3rd Int. Conf. Soil . Mech. and Foundn Engrg, Zurich, 2, 288-293.

TOMS, A.H. and BARTLETT, D.L. (1962). Applications of soil mechanics in the design of stabilizing works for embankments, cuttings and track formations. Proc. Instn Civil Engrs, 21, 705-732.

VALENTIN, H. (1954). Der Landverlust in Holderness, Ostengland, von 1852 bis 1952. Erde, 6, $296-315$.

VINER-BRADY, N.E. V. (1955). Folkestone Warren landslips: remedial measures 1948-50. Proc. Instn Civil Engrs, Railway Paper No. 57, 429-441.

WARD, W. H. (1948). A coastal landslip. Proc. 2nd Int. Conf. Soil Mech. and Foundn Engrg, Rotterdam, 2, 33-38.

WILSON, R. L. and SMITH, A.K.C. (1983). The construction of a trial embankment on the foreshore at Llanddulas. Shoreline Protection, 223-233. Thomas Telford Lid, London.

WOOD, A. M. M. (1955). Folkestone Warren landslips: investigations, 1948-50. Proc. Instn Civil Engrs, Railway Paper No. 56, 410-428.

\section{APPENDIX}

Derivation of equation defining location of Neutral Points (Hutchinson 1977, 1984).

If the slip surface considered is, for example, non-circular with a low $d / L$ ratio, the Conventional Method of analysis may be applied with good accuracy (Skempton and Hutchinson, 1969).

Let the original factor of safety, $F_{0}$ be expressed as

[2] $F_{0}=\frac{\Sigma \text { available resisting forces }}{\Sigma \text { driving forces }}=\frac{\Sigma R_{0}}{\Sigma D_{0}}$

The new factor of safety, $F_{1}$, with the influence load $\Delta W$ acting on slice $i$, will be

[3] $F_{1}=\frac{\Delta N_{i}^{\prime} \tan \phi^{\prime}+\Sigma R_{0}}{\Delta W \sin \alpha_{i}+\Sigma D_{0}}$

where $\Delta N_{i}^{\prime}$ is the change in effective normal force produced on the base of slice $i$ by the influence load $\Delta W$. This is given by

[4] $\Delta N_{i}^{\prime}=\Delta W\left(\cos \alpha_{i}-\bar{B} \sec \alpha_{i}\right)$

hence 
[5] $\frac{F_{1}}{F_{0}}=\frac{\left.\Sigma D_{0}\left[\Delta W \cos \alpha_{i}-\bar{B} \sec \alpha_{i}\right) \tan \phi^{\prime}+\Sigma R_{0}\right]}{\Sigma R_{0}\left(\Delta W \sin \alpha_{i}+\Sigma D_{0}\right)}$

Now, at the Neutral Point

$$
\frac{F_{1}}{F_{0}}=1.0 \quad \text { and } \quad \alpha_{i}=\alpha_{n} \quad \text { (Fig. 31a). }
$$

The position of the Neutral Point is thus given by

[6] $\tan \alpha_{n}=\left(1-\bar{B} \sec ^{2} \alpha_{n}\right) \frac{\tan \phi^{\prime}}{F_{0}}$

Alternatively, if the slip surface is circular, the Bishop Simplified Method (Bishop, 1954) may be used as the basis for the analysis. Then, with the symbols used in that paper,

[7] $F_{0}=\frac{1}{\Sigma W \sin \alpha} \Sigma\left\{\left[c^{\prime} b+\tan \phi^{\prime}(W-u b)\right] \frac{\sec \alpha}{1+\frac{\tan \phi^{\prime} \tan \alpha}{F_{0}}}\right\}$

Hence, putting

[8] $\left[c^{\prime} b+\tan \phi^{\prime}(W-u b)\right]=J$

and

[9] $\frac{\sec \alpha}{1+\frac{\tan \phi^{\prime} \tan \alpha}{F_{0}}}=M_{0}$

[10] $F_{0}=\frac{1}{\Sigma W \sin \alpha} \sum\left(J M_{0}\right)$

Then the new factor of safety, $F_{1}$, with the influence load $\Delta W$ acting on slice $i$, is [11] $F_{1}=\frac{1}{\Delta W \sin \alpha_{1}+Z W \sin \alpha}\left[\Delta W \tan \phi^{\prime}(1-\bar{B}) M_{l_{s}}+Z\left(J M_{1}\right)\right]$

where

[12] $M_{1}=\frac{\sec \alpha}{1+\frac{\tan \phi^{\prime} \tan \alpha}{F_{1}}} \quad$ and $\quad M_{1 i}=\frac{\sec \alpha_{i}}{1+\frac{\tan \phi^{\prime} \tan \alpha_{i}}{F_{1}}}$

thus

[13] $\frac{F_{1}}{F_{0}}=\frac{\left[\Delta W \tan \phi^{\prime}(1-\bar{B}) M_{1 i}+\Sigma\left(J M_{1}\right) \Sigma W \sin \alpha\right.}{\left(\Delta W \sin \alpha_{i}+\Sigma W \sin \alpha\right) \Sigma\left(J M_{0}\right)}$

Now, at the Neutral Point

$$
\frac{F_{1}}{F_{0}}=1.0, \quad \alpha_{\imath}=\alpha_{n} \text { and } M_{1_{i}}=M_{1_{n}}=M_{0 i}=M_{0_{n}}
$$

hence

[14] $\sin \alpha_{n}=\frac{(1-\vec{B}) \sec \alpha_{n}}{1+\frac{\tan \phi^{\prime} \tan \alpha_{n}}{F_{\eta}}} \cdot \frac{\tan \phi^{\prime}}{F_{0}}$

which reduces to

[6] $\tan \alpha_{n}=\left(1-\bar{B} \sec ^{2} \alpha_{n}\right) \frac{\tan \phi^{\prime}}{\bar{F}_{0}}$

as before. 


\section{英国に括け等地すべりとその対策}

J. N. Hutchinson 博士は，英国・ロンドン大学の Imperial college の土木工学部の教授で，地すべりの分野で 世界的に広く活躍され，多数の地すべり、関する論文を 発表されて招ら机采す。読者の方々も，博士の書かれた 論文を通して既化名前を御存知の方も多いことだと思い ます。

博士は, 先年, 日本で UNESCO の「地すべりと土石 流のノモグラフ」の編集委員会の開催の折, 初来日さ れ，東京，大阪での「地すべり，土石流，土質基礎に関 するUNESCO EXPERT による講演会」の際に，英国 の地すべりの現状とその対策について御講演いただきま した。

地すべり技術者にとってその内容特よびスライド写真 は非常に興味あるるので, 再度, 地すべり学会誌への寄 稿を揞願いしましたところ，快く御承諾いただき，論文 内容を新たにして笴稿いただきました。ここに寛大な， J. N. Hutchinson 博士飞感謝するとともK，寄稿論文内 容について概略報告します。

まず,当論文の最初の章は, J.N. Hutchinson博士飞 よって提案された，英国の地すべりの型分類が示されて います（図-1）。これら型分類を通して，英国で発生す る主要な地すべりについて, 発生位置図（図-2）ととも K, 海岸地带飞発生する地すべり, 内陸部自然斜面に発 生する地すべり, 切土や盛土等の人工的原因纪よって発 生する地すべりに 3 分類し, それぞれ実態と特徽につい て記されています。

I . 海岸地带飞発生する地すべり飞轨いては，年間 $8 \mathrm{~m}$ 己侵食される簓所があって種々の地すべりが発生し て物り，1）強度の海岸侵食を受ける堅い䈀の多い粘 土地带で発生する地すべりとして, 1971年, London clay 崖で発生した，Warden point の回転性地すべり（図-3） と，1953年, Herne Bay 付近の London clay 崖中飞発 生した，複合，グラーベン型の地すべり（図-4），が紹 介されています。2）次に，中程度の海岸侵食を受ける 堅い黾裂の多い粘土地带（海岸侵食の程度については脚 注に詳述されているので参照されたい）に発生する地す ベりとして, Herne Bay 近くの London clay 崖中に発生 した mud slide（図-5,6）を紹介しています。3）キャ ップロック状をなす堅い龟裂粘土地帯の地すべりとして, Garron Point の大規模な回転泩の地すべりを紹介し，キ ャップロックの性状について詳述しています。4）第 4
紀の堆積土中に発生する地すべりとして， East Anglia の海岸地带化多発する地すべりを揭げその一例として図 -9飞 cromer 回転地すべりを, 図-10飞はこれら地域の斜 画末端侵食防止工事の例が示されています。5）岩塊中 そ発生する地すべりとして，ドーバー海岸で有名な白亜 崖飞発生した落石（図-11), 図-12 に間隙水圧上昇を原 因とした流動すべり (flow slide) を，図-13にはトップ リング崩壊の事例を詳述しています。

II. 内陸部に発生する地すべりの事例としては，現 在, 英国に特いては侵食作用はさ注ど強くないが, 更新 世の水河期に括けるソリフラクションに上る崩土が厚く 堆積し，これら地域炕地すべりが多発して呿り，図-14 飞Swindon 近くの道路建設に伴なら層すべりが報告さ れています。また London clay 中発生した地すべりの 発生状況を図-16〜図一-17亿示してい要す。

III.人工的原因による地すべりの例としては，図一18 に切土を原因としたLondon clay 中飞発生 Wembley の 地すべりと144名の人命を奪った济た山の地すべり（図一 19）を紹介しています。

10頁からは，地すべり対策工炕いて報告されて扔 り，特排水工Kついては，浅層地下水排除，深層地下 水排除和よび中間層地下水排除飞分類し, 図-21飞トレ ンチ排水工の事例が，図-22k扶壁型排水工(counterfort drain）とトレンチ型排水工のモデル図が示され，典型 的なトレンチ型排水工の概念図が示されています。さら に㘠-24kは，このトレンチ型排水工の効果について， 理論計算と現場観測データの比較がなされています。深 層地下水排除例として図-28に，排水ギャラリーによる 施工例が，中間層地下水排除の例として，図-30 白本 でよく観察される集水井排水工の施工例が示されていま す。

次涂斜面の安定度の概念（安全率の変化）から切土， 盛土の影響とついて詳述して坅り，斜面末端部の盛土工 の事例を図-32炕報告しています。

最後にすべり面の置換工法の事例とアンカー工等の施 工事例が図-34 35飞示されています。

紙面の都合上，論文の内容について詳細佂紹介できず 図面のみ簡単に紹介しました。ぜび原論文の一読を招す すめする次第です。

（文責 : 建設省 吉松弘行） 